\title{
Endocrine and other physiologic modulators of perinatal cardiomyocyte endowment
}

\section{S S Jonker and S Louey}

Knight Cardiovascular Institute Center for Developmental Health, Oregon Health and Science University, Portland, Oregon 97239, USA

\author{
Correspondence \\ should be addressed to \\ S S Jonker \\ Email \\ jonkers@ohsu.edu
}

\begin{abstract}
Immature contractile cardiomyocytes proliferate to rapidly increase cell number, establishing cardiomyocyte endowment in the perinatal period. Developmental changes in cellular maturation, size and attrition further contribute to cardiac anatomy. These physiological processes occur concomitant with a changing hormonal environment as the fetus prepares itself for the transition to extrauterine life. There are complex interactions between endocrine, hemodynamic and nutritional regulators of cardiac development. Birth has been long assumed to be the trigger for major differences between the fetal and postnatal cardiomyocyte growth patterns, but investigations in normally growing sheep and rodents suggest this may not be entirely true; in sheep, these differences are initiated before birth, while in rodents they occur after birth. The aim of this review is to draw together our understanding of the temporal regulation of these signals and cardiomyocyte responses relative to birth. Further, we consider how these dynamics are altered in stressed and suboptimal intrauterine environments.
\end{abstract}

\author{
Key Words \\ - heart development \\ - cardiomyocyte growth \\ - terminal differentiation \\ - angiotensin II \\ - insulin-like growth factor 1 \\ - cortisol \\ - thyroid hormone \\ - hypoxia \\ - hypertension \\ - birth
}

Journal of Endocrinology (2016) 228, R1-R18

\section{Introduction}

Since the late 20th century it has been recognized that, near the time of birth, growth of the mammalian heart transitions from proliferation of contractile cardiomyocytes to cellular enlargement (Adler 1975, Bishop \& Hine 1975, Clubb \& Bishop 1984, Rumyantsev 1991). The number of cardiomyocytes continuously decreases with age in adulthood and, contribution of stem cell-derived myocytes notwithstanding, progressive loss of adult myocytes is associated with heart failure (Olivetti et al. 1991, Pessanha \& Mandarim-de-Lacerda 2000, Levkau et al. 2008, Laflamme \& Murry 2011). Thus, perinatal cardiomyocyte endowment is consequential for life-long health. Factors in the fetal environment resulting from both normal and stressed pregnancies act on the developing heart to modulate cardiomyocyte number. Many of these regulatory factors change dramatically at or near the time of birth.

Proliferation, terminal differentiation, attrition and cellular enlargement are processes that must all be considered in the regulation of cardiomyocyte number and the size of the developing heart. Each of these cellular processes can be to some extent governed separately. Regulatory factors may effect different outcomes in a suboptimal intrauterine environment compared to normal development. Thus, it is critical to understand the dynamics of normal cardiomyocyte growth during this period before we can fully appreciate the outcomes following prenatal stress. The chronically catheterized fetal sheep model has enabled a detailed examination of how the fetal cardiac environment shapes cardiomyocyte

Published by Bioscientifica Ltd 
growth, maturation and endowment. The purpose of this review is to summarize what is known about endocrine and other regulators of growth and maturation of cardiomyocytes in the immature ovine heart and how these factors may contribute to normal development.

\section{Sheep as a model of cardiac development}

Our knowledge about in vivo regulation of fetal cardiomyocytes depends heavily on animal models because cardiac biopsies are rarely available from healthy human infants. Likewise, sampling of blood and direct hemodynamic measurements of the healthy human fetus are very rarely undertaken. The fetal sheep model has filled this gap because it tolerates chronic surgical instrumentation, allowing serial blood sampling and measurement of hemodynamic factors. Additionally, altered endocrine or hemodynamic fetal environments can be experimentally produced to investigate the regulation of cardiac outcomes.

Specific interspecies differences must be borne in mind when extrapolating knowledge of sheep cardiac development to the human. Adult sheep are a good model of the adult human cardiac function (Milani-Nejad \& Janssen 2014), and form the basis for much of our knowledge of cardiac function in the immature heart (Rudolph 2009). Sheep have a dissimilar placenta to humans, which may influence the materno-fetal nutritional, hemodynamic and hormonal milieu guiding cardiac development (Carter 2007, Barry \& Anthony 2008). While most human pregnancies are singletons, sheep commonly bear singletons or twins; multiple pregnancy in sheep affects placental nutrient transfer, and consequently reduces fetal growth, although the magnitude of this effect is only half that as occurs in human twinning (Gardner et al. 2007, The et al. 2010, van der Linden et al. 2013). The same hormones are responsible for maintenance of pregnancy and initiation of parturition in humans and sheep, and some of these hormones influence heart growth (in sheep, there is late gestation systemic withdrawal of progesterone that is unmatched in humans; Challis et al. 2000). The gestational period of a sheep is slightly more than half that of a human, long enough for good resolution of timedependent growth-regulating effects in experimental studies. Sheep are born somewhat more mature than humans in regards to their ability to stand and walk, but many of their physiological systems have similar relative rates of development, including kidney and brain (Hinchliffe et al. 1992, Gimonet et al. 1998, Back et al. 2006). Notably, in the perinatal periods of humans and sheep, cardiomyocyte numbers experience similar plateaus, cardiomyocyte cell cycle activity declines similarly, and polyploidy or binucleation increase rapidly (Adler \& Costabel 1975, Adler \& Costabel 1980, Kim et al. 1992, Huttenbach et al. 2001, Burrell et al. 2003a, Jonker et al. 2015). In this review we focus on data from humans and sheep, except where critical data is available only from other species.

\section{Modes of growth in the fetal sheep heart}

\section{Proliferation}

Proliferation of immature contractile cardiomyocytes is well established in all vertebrate orders (Rumyantsev 1991), and is responsible for increasing ovine cardiomyocyte number throughout gestation and the perinatal period (Fig. 1 and 2A and C; Burrell et al. 2003b, Jonker et al. 2007a, Jonker et al. 2015). It has long been thought that in mammals this process ends around the time of birth, and that cardiomyocyte endowment for life is set in the prenatal period (Thornburg et al. 2011). New evidence suggests that proliferation of contractile cardiomyocytes increases cell number in neonatal sheep (Jonker et al. 2015) and even in the juvenile human (Mollova et al. 2013). Although division of contractile cells in the adult heart has been highly debated, stem cell replacement of cardiomyocytes is now recognized to occur (reviewed in Laflamme \& Murry 2011). Nevertheless, net cardiomyocyte number declines continuously between young adulthood and senescence in the human

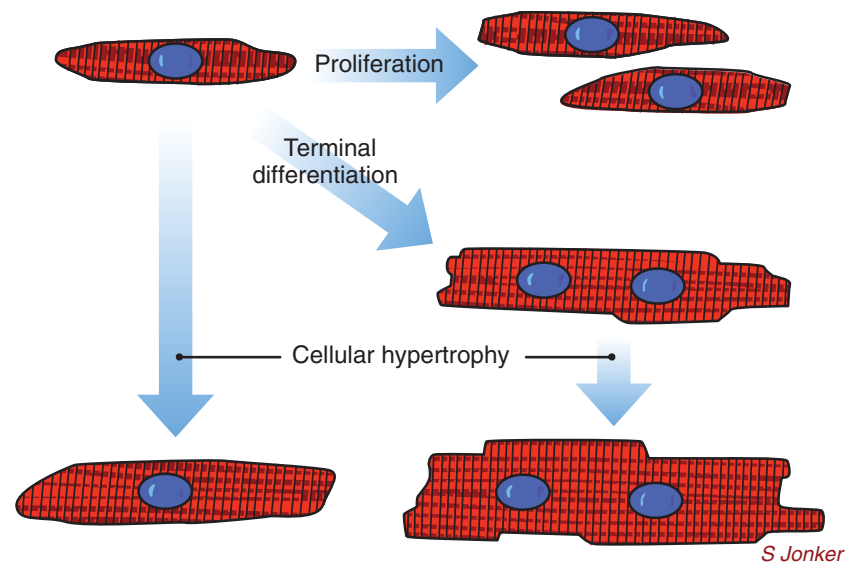

Figure 1

Modes of cardiomyocyte growth in the fetal heart. Mononucleated cardiomyocytes have the potential to proliferate. They can also become binucleated, indicative that they are unable to undergo further cytokinesis. They can, however, replicate their DNA and become polyploid (not shown). Both mononucleated and binucleated cardiomyocytes can undergo cellular enlargement, or apoptosis (not shown).

Published by Bioscientifica Ltd 

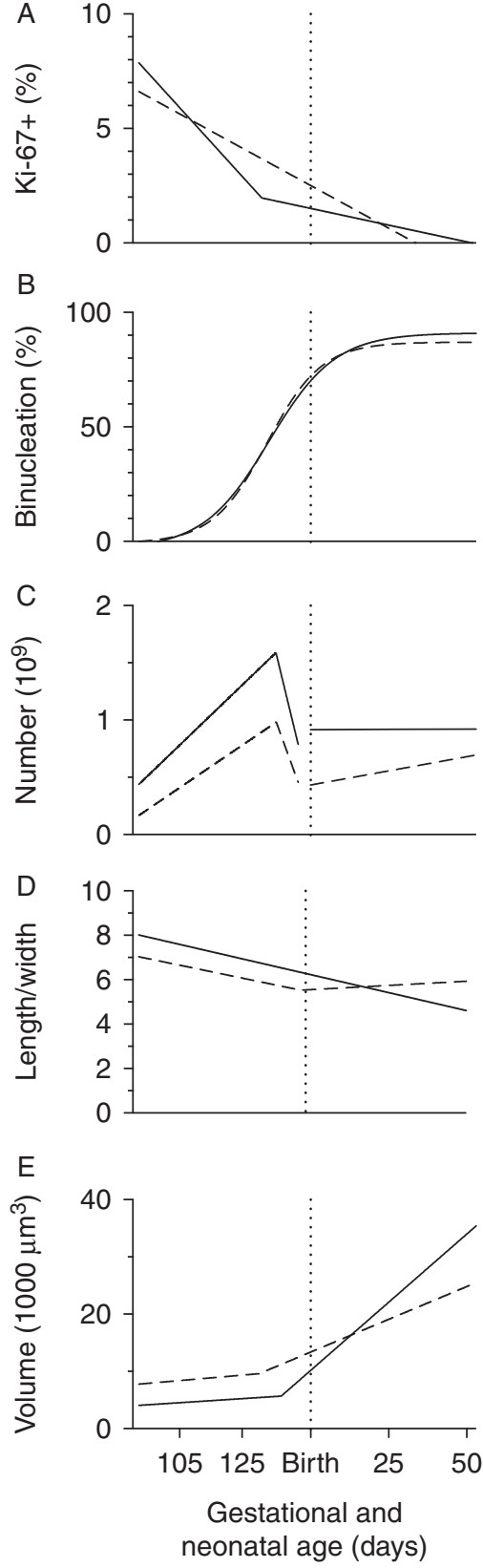

Figure 2

Regulation of cardiomyocyte growth and maturation in the normallygrowing fetal and neonatal sheep left ventricle (LV; solid line) and right ventricle (RV; dashed line). Cell cycle activity as assessed by Ki-67 positivity (A) supports cardiomyocyte proliferation and terminal differentiation. Binucleation of cardiomyocytes (B) is an index of terminal differentiation, after which cells infrequently enter the cell cycle, and even less frequently undergo cytokinesis. Consequent to myocyte proliferation, cell number (C) increases rapidly in the fetus (and slowly in the neonatal RV). Cell attrition reduces myocyte number prior to birth in both ventricles. Cardiomyocytes typically grow more rapidly in width than length, decreasing their lengthto-width ratio (D), except after birth in the neonatal RV. Myocyte volume (E) increases slowly in the fetus, but more rapidly after birth (much more so in the LV). Most changes in cell growth and maturation rates occur before birth. Data from Jonker et al. (2007b) and Jonker et al. (2015).
(Olivetti et al. 1991), confirming the importance of cardiomyocyte proliferation in the young heart.

Immature contractile cardiomyocytes that proliferate in perinatal mammals are typically mononucleated and diploid (2N; Clubb \& Bishop 1984, Rumyantsev 1991, Jonker et al. 2007a). This cardiomyocyte phenotype predominates in the fetal human (Adler \& Costabel 1980) and sheep (Burrell et al. 2003a, Jonker et al. 2007a, Bensley et al. 2010, Jonker et al. 2015). In the large mammal, it is unknown whether mononucleated, diploid cardiomyocytes at a given age are all equally proliferative. In the embryonic mouse heart, lineages of cells form related clusters layered in epicardial-to-endocardial columns (Pijnappels et al. 2010), implicating proliferative contribution from many or most cardiomyocytes. Cell culture experiments also suggest that most rat cardiomyocytes proliferate at mid-gestation, but fewer do so at term (Burton et al. 1999). This evidence suggests that many or most mononucleated cardiomyocytes increase cell number by proliferation through at least mid-gestation, after which fewer of these cells may carry out most of the proliferative activity in the heart.

\section{Terminal differentiation}

Terminal differentiation involves permanent cell cycle arrest, or senescence, after which DNA replication followed by cytokinesis no longer occurs (Figs 1 and 2B). The intracellular mechanisms regulating terminal differentiation have not been conclusively determined, but candidate genes have been described (Paradis et al. 2014). Terminal differentiation of cardiomyocytes appears to be tightly regulated, as evidenced by the exceeding rareness of rhabdomyoma and rhabdomyosarcoma primary cardiac tumors, which are found only in about 1 of 6000 human autopsies (Lam et al. 1993). Supporting this conclusion is a higher incidence of cardiac tumors found in fetuses, in which cardiomyocyte proliferation is active (Holley et al. 1995, Uzun et al. 2007).

Cell cycle activity, as detected by Ki-67, phosphohistone-3, proliferating cell nuclear antigen (PCNA) and other markers of mitosis, leads to DNA replication concluding in either cytokinesis or stable binucleation. Because of this, and the observation that binucleated cardiomyocytes are rarely noted to have reentered the cell cycle, terminal differentiation has been synonymous with binucleation in the sheep and rodent (Clubb \& Bishop 1984, Soonpaa et al. 1996, Barbera et al. 2000, Burrell et al. 2003a, Jonker et al. 2015). In humans, failure of nuclear division following DNA replication frequently results in

Published by Bioscientifica Ltd. 
polyploid nuclei $(4 \mathrm{~N}, 8 \mathrm{~N}$ or greater; Brodsky et al. 1994 , Adler et al. 1996). Polyploidy of cardiomyocytes also occurs in sheep and rodents, but to a much lesser extent (Adler et al. 1996, Bensley et al. 2010). It is unknown if polyploidy also indicates terminal differentiation.

Whether binucleation (and perhaps polyploidy) are incidental or integral to terminal differentiation is also unknown. Cell culture experiments suggest that the majority of cardiomyocytes from term fetal mice have very little proliferative potential and only a subset retain the abundant potential of the mid-gestation heart (Burton et al. 1999). This implies that many myocytes have withdrawn from proliferative activity prior to binucleation (Burton et al. 1999). Further, cardiomyocyte proliferative activity in mice is temporally separated from binucleation, again suggesting that terminal differentiation may precede binucleation or polyploidy (Soonpaa et al. 1996).

\section{Apoptosis}

A counterpoint to cellular proliferation is the process of programmed cell death, or apoptosis. Transitory cardiomyocyte apoptosis has been described to prune the rodent heart at birth (Kajstura et al. 1995, Fernandez et al. 2001). This cell loss is described as especially heavy in the right ventricle (RV), and is thought to play a role in remodeling the heart in the context of postnatal hemodynamic patterns. Indeed, rates of myocardial apoptosis are also higher in week-old lambs than 6-8 week-old lambs (Karimi et al. 2004), suggestive of higher perinatal receptiveness to apoptotic signals. However, in normally-developing sheep, the perinatal bulk attrition of cardiomyocytes may occur immediately prior to birth (Fig. 2C; Jonker et al. 2015). Although the sheep heart is sensitive to proapoptotic stimuli in late gestation and in the early neonate, the ontogeny of apoptosis in the perinatal heart (especially in the large mammal) and its relative contribution to the changing cellular landscape during this transitory period remains poorly understood (Bae et al. 2003, Hammel et al. 2003, Caldarone et al. 2004, Karimi et al. 2004).

\section{Cellular enlargement}

Cellular enlargement, or hypertrophy, is the primary growth mode of cardiomyocytes in the adult heart, whether in response to exercise, cell loss with aging, or as part of a disease process (White et al. 1987, Adler et al. 1996, Kramer et al. 1998). Fetal cardiomyocytes are small compared to those of the adult and, in the normally growing fetus, change little in size until after birth (Fig. 2D and E; Smolich et al. 1989, Burrell et al. 2003a, Jonker et al. 2015). However, when stimulated, cardiomyocytes can increase both in length and width in the near-term fetus (Barbera et al. 2000, Jonker et al. 2007b). Increasing the width of cardiomyocytes requires development of the t-tubule system for excitation-contraction coupling (Bers 2002, Seki et al. 2003). The narrow diameter of immature cardiomyocytes allows them to function before development of the t-tubule network, which matures in the perinatal period (Legato 1979, Sheridan et al. 1979, Forsgren \& Thornell 1981, Maylie 1982).

Interestingly, postnatal cardiomyocyte hypertrophy is typically associated with increased production of the contractile elements so that the enlarged cell can perform more work, but this is not necessarily the case in the fetus (Barbera et al. 2000). The contractile elements in immature cardiomyocytes are relatively less dense and organized near the plasma membrane (Brook et al. 1983, Smolich et al. 1989). Increasing cardiomyocyte width without proportional synthesis of contractile proteins may confer an immediate mechanical advantage by adjusting the ventricular wall thickness-to-chamber radius ratio to reduce wall stress. Most investigations that include fetal cardiomyocyte hypertrophy have focused on changes in gross cell dimensions rather than synthesis and organization of contractile machinery. Differential regulation of these processes remains to be investigated.

\section{Non-cardiomyocyte growth}

The heart is composed not only of cardiomyocytes, but fibroblasts, endothelial cells, smooth muscle, pericytes, other cell types and the matrix. Cardiomyocytes occupy an increasing percentage of the myocardium with advancing gestational age and in the neonate (Smolich et al. 1989). Simultaneously, the relative amount of matrix and vasculature in the myocardium declines (Wearn 1941, Smolich et al. 1989, Marijianowski et al. 1994). Factors that regulate perinatal cardiomyocyte growth may also regulate other components of the immature heart. These changes may have profound implications for life-long cardiac function, but are outside the scope of this review.

\section{Regulatory signals associated with birth}

The peripartum hormonal milieu is in a state of flux, with gestational decreases in vasoactive hormones such as angiotensin II (AII), increases in growth-promoting

Published by Bioscientifica Ltd 
hormones such as insulin-like growth factors (IGF) and maturational hormones such as cortisol and thyroid hormones; most are magnitudes higher in the days after birth. Each of these circulating factors have individual effects on cardiomyocyte growth kinetics and, in concert with physical and local factors, balance the cellular processes that determine cardiomyocyte endowment in the perinatal period. The transition from intra- to extrauterine life is also met with the loss of the placenta and immediate increases in oxygenation, cardiac afterload and systemic arterial pressure. Changes in some factors precede birth, reflecting their critical role in preparing the fetus for the stress of parturition and extrauterine life.

\section{Angiotensin II}

The renin-angiotensin system is essential for the maintenance of normal fetal systemic arterial pressure (Scroop et al. 1992, Anderson et al. 1994, Faber et al. 2011). Circulating AII steadily decreases from $0.04-0.05 \mathrm{ng} / \mathrm{ml}$ in fetuses $<120$ days gestational age (dGA; term $\sim 147 \mathrm{~d}$ GA) to $0.02-0.03 \mathrm{ng} / \mathrm{ml}$ in the final week before term (Fig. 3; Rosenfeld et al. 1995). In the first postnatal week, these levels are more than 25 times higher than in the prepartum period but then decline soon after (Velaphi et al. 2007). Fetal hypoxia and cortisol can both increase circulating plasma renin activity (PRA) and AII levels (Broughton Pipkin et al. 1974, Forhead et al. 2000); thus, AII may play a role in cardiomyocyte changes associated with hypoxia and fetal stress.

AII receptor 1 (AT1), which is the most common receptor subtype in the adult heart, is very low in midgestation but increases abruptly around 120 days of
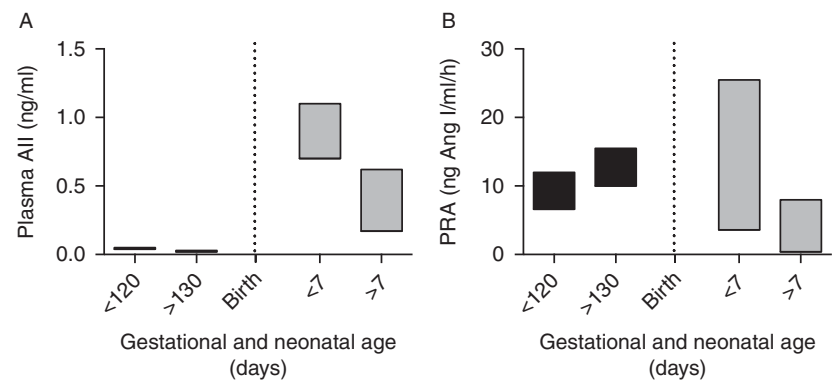

Figure 3

Published ranges for (A) angiotensin II (AII) and (B) plasma renin activity (PRA) in normal fetal (black) and newborn (grey) sheep. Owing to the short half-life of All, PRA is often measured instead of All (renin converts angiotensinogen to angiotensin I). Data from Broughton Pipkin et al. (1974), Fleischman et al. (1975), Louey et al. (2000), Louey et al. (2007), Rosenfeld et al. (1995), Siegel and Fisher (1980), Velaphi et al. (2007). gestation (Table 1; Burrell et al. 2001). In contrast, AT2 is highest in mid-gestation and declines towards term. Angiotensin converting enzyme (ACE) mRNA levels, which converts angiotensin I to AII, also increases abruptly near term and remains high in the neonate (Reini et al. 2009).

The outcome of AII signaling in fetal sheep cardiomyocytes is complex, in part depending on whether the experiment is conducted in isolated cells or in utero. AII causes near-term fetal sheep cardiomyocytes to proliferate in culture, contrary to its hypertrophic effect in cultured neonatal rat cardiomyocytes (O'Tierney et al. 2010a, Sundgren et al. 2003a). In contrast, AII infusion in utero increases ovine heart growth via myocyte hypertrophy and maturation (Segar et al. 2001, Norris et al. 2014, Sandgren et al. 2015). Atrial natriuretic peptide (ANP) inhibits AII-stimulated fetal cardiomyocyte proliferation in culture (O'Tierney et al. 2010a); increased arterial pressure resulting from in utero AII infusion may simultaneously inhibit proliferation by stimulating ANP release while stimulating cellular enlargement and terminal differentiation via increased wall stress. When the increase in systemic pressure induced by exogenous AII is mitigated by co-infusion with a nitric oxide donor, cardiac hypertrophy, cellular hypertrophy and accelerated terminal differentiation are all eliminated (Sandgren et al. 2015). Interestingly, cardiomyocyte PCNA staining remains elevated, suggesting cellular proliferation despite lack of gross cardiac hypertrophy (Sandgren et al. 2015). Chronic blockade of ACE inhibits fetal cardiac proliferative growth, although interpretation of this effect is complicated by dramatically lowered arterial pressure (O'Tierney et al. $2010 b$ ). The findings of these studies taken together suggest that the primary effect of AII on cardiomyocyte growth in utero is a result of altered systemic arterial pressure load.

\section{Insulin-like growth factors}

IGF1 and IGF2 are required for normal fetal growth (Fowden 2003, Brown 2014). Circulating IGF1 steadily increases with gestation, while IGF2 levels remain relatively high throughout gestation (Fig. 4; Carr et al. 1995). After birth, high IGF1 levels are maintained (Crespi et al. 2006, Long et al. 2011). Interestingly, ontogenic trends in the cardiac mRNA levels of IGF1 and IGF2 do not mirror circulating levels, with expression decreasing towards term for both genes (Table 1; Cheung et al. 1996, Reini et al. 2009). IGF1 and IGF2 appear to be regulated by oxygen and nutrition levels; thus, prenatal stresses such as

Published by Bioscientifica Ltd 
Table 1 Cardiac receptors and factors and circulating binding proteins responsible for signal transduction and modulation in the fetal sheep heart.

\begin{tabular}{|c|c|}
\hline $\begin{array}{l}\text { Growth } \\
\text { factor }\end{array}$ & Pathway component \\
\hline \multirow[t]{3}{*}{ All } & AT1 \\
\hline & AT2 \\
\hline & ACE (cardiac mRNA) \\
\hline \multirow[t]{7}{*}{ IGF } & IGF1 (cardiac mRNA) \\
\hline & IGF2 (cardiac mRNA) \\
\hline & IGF1R (cardiac mRNA) \\
\hline & IGF2R (cardiac mRNA) \\
\hline & IGFBP-2 (circulating) \\
\hline & IGFBP-2 (cardiac mRNA) \\
\hline & IGFBP-3 (circulating) \\
\hline Cortisol & GR (cardiac mRNA) \\
\hline & $M R$ (cardiac mRNA) \\
\hline
\end{tabular}

\section{Change from mid to late gestation}

Very low, rapid increase from about 120 days of gestation High and decreasing

Low, increasing abruptly just before term

Increases slightly from second trimester, decreasing through second half of gestation

Decreasing continuously from second trimester Slight decline with advancing gestational age Decline with advancing gestational age Increasing throughout, peaking before birth

Dramatic decline with advancing gestational age Unchanged throughout

Declining in the LV; unchanged in the RV Declining in the LV; unchanged in the RV

\section{Source}

Burrell et al. (2001)

Burrell et al. (2001)

Reini et al. (2009)

Cheung et al. (1996)

Cheung et al. (1996)

Cheng et al. (1995), Reini et al. (2009)

Reini et al. (2009)

Carr et al. (1995), Crespi et al. (2006)

Reini et al. (2009)

Carr et al. (1995), Crespi et al. (2006)

Reini et al. (2009)

Reini et al. (2009) placental insufficiency and intrauterine growth restriction are usually associated with decreased circulating IGFs (Owens et al. 1994).

Developmental regulation of IGF receptors (IGFR) probably modifies cardiomyocyte responses to circulating IGF levels. IGFR1 mRNA in the left ventricle (LV) declines with advancing gestational age (Table 1 ; similar to maturational changes found in the rat heart), but changes little in the RV (Cheng et al. 1995, Reini et al. 2009). The mRNA for IGFR2, the clearance receptor, is highest in midgestation and declines towards term and in the neonate (Reini et al. 2009). Nutrient restriction increases fetal cardiac IGF2R levels at a post-transcriptional level (Dong et al. 2005), suggesting that our understanding of normal cardiac IGFR levels in development may be incomplete without knowing the protein levels. Further, insulin receptor (IR) may share the pro-survival signaling of IGFR1, and new data in the rodent heart suggests an important role for insulin receptor substrates 1 and 2 downstream of both IR and IGFR1 for the regulation of cardiomyocyte metabolism and survival (Qi et al. 2013). IGF binding proteins (IGFBP) also substantially modify IGF system signaling by sequestering IGF, modifying the interaction of IGF with the cell, and through IGFindependent cell signaling (Baxter 2014). IGFBP-2 can potentiate IGF signaling and is the primary binding protein in the fetus; serum levels progressively increase throughout gestation and peak before birth (Carr et al. 1995, Crespi et al. 2006). In contrast, cardiac IGFBP-2 mRNA levels decline dramatically with advancing age (Reini et al. 2009). IGFBP-3 is the primary form in the adult, acting to stabilize IGF and prolong its circulating half-life. Serum levels are largely stable in utero (Carr et al. 1995, Crespi et al. 2006). Together, these data suggest a complex in utero IGF regulatory environment.

Overall, studies support the pro-mitogenic role of IGF1 in the fetal sheep heart. IGF1 stimulates proliferation in cardiomyocytes cultured from both mid-gestation and near-term fetal sheep (Sundgren et al. 2003b, Chattergoon et al. 2014), although whether it also causes cellular enlargement at term is debated (Sundgren et al. 2003b, Wang et al. 2012). When chronically infused into the fetal circulation, IGF1 causes massive cardiac enlargement by the stimulation of cellular proliferation without increased cellular enlargement or terminal differentiation (Sundgren et al. 2003b). After a short, transient exposure, gross cardiac hypertrophy was not evident, although there was

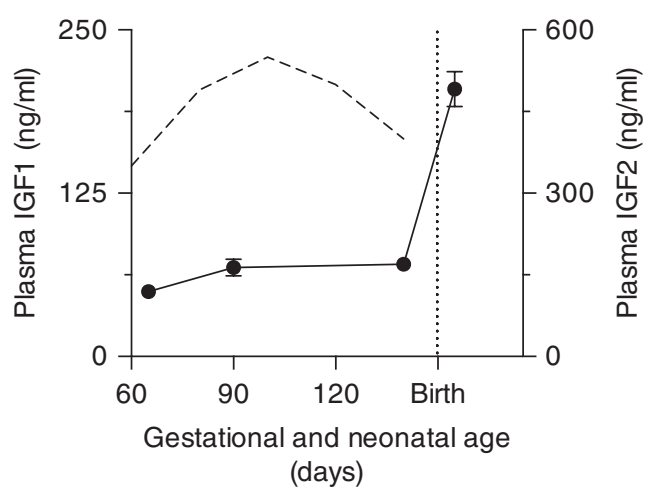

Figure 4

Circulating insulin-like growth factor 1 (IGF1; solid line, mean \pm s.E.M.) and insulin-like growth factor 2 (IGF2; dashed line, mean) in normal fetal and newborn sheep. Data from Carr et al. (1995) and Crespi et al. (2006). 
a suggestion of sex-specific regulation of cellular enlargement (Lumbers et al. 2009). Transient exposures complicate interpretation because the fetal heart will subsequently adjust growth to normalize heart weight, probably to match heart size to somatic circulatory demand (Jonker et al. 2011a).

\section{Cortisol}

Circulating levels of cortisol are negligible in the sheep $(<10 \mathrm{ng} / \mathrm{ml})$ until the last 10 days before term, when levels rapidly increase (Fig. 5). The surge in the final days of gestation is believed to be a push to mature key organ systems in preparation for the transition to extrauterine life. Increased fetal cortisol is essential to initiating parturition at least in the sheep (Liggins 1968), it can be seen that the prepartum surge consistently commences 7-10 days before birth (Magyar et al. 1980). Prenatal stresses such as placental insufficiency are known to increase fetal cortisol levels (Joyce et al. 2001, Morrison et al. 2007), and may be sufficient to induce preterm birth in subsets of growth-restricted fetuses (Cock et al. 2001a), whereas those with normal cortisol levels will be born at term (Louey et al. 2000). Exogenous cortisol elevates arterial pressure (Wood et al. 1987, Tangalakis et al. 1992), renin and AII (Forhead et al. 2000), and triiodothyronine ( $\mathrm{T}_{3}$; see next section), thus these other factors must be taken into consideration when designing and interpreting experiments.

Glucocorticoid receptor (GR) and mineralocorticoid receptor (MR) mRNA levels (encoded by NR3C1 and NR3C2 respectively) in the LV decline from mid- to late gestation, but change relatively little thereafter (Table 1 ; Reini et al. 2009). In contrast, neither mRNA changes in the $\mathrm{RV}$, save for a transient depression of $M R$ at 100 days of gestation. There can be post-transcriptional regulation
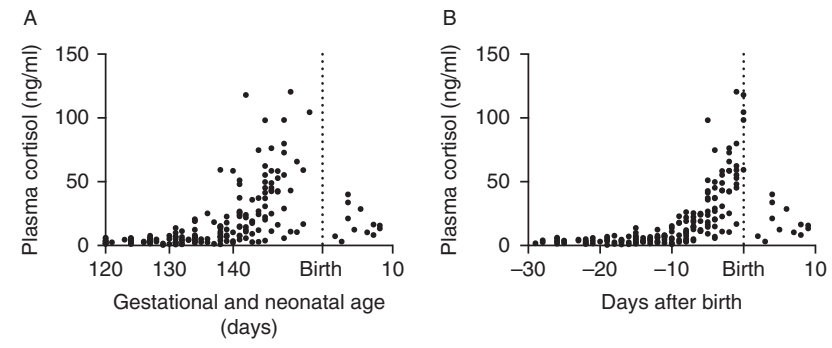

Figure 5

Circulating cortisol levels in normal fetal and newborn sheep expressed relative to $(A)$ gestational age, or $(B)$ the time of birth. Data from Louey et al. (2000), Magyar et al. (1980). levels for both receptors, as for example in the developing sheep kidney (Hantzis et al. 2002); therefore, caution is urged in interpreting this data in the absence of receptor binding or protein levels.

Although clearly a critical hormone for the initiation of parturition and maturation of organs such as the lungs, the direct role of cortisol in regulating perinatal cardiomyocyte growth and maturation remains unclear. Infusion of sub-pressor levels of cortisol into the near-term fetal sheep coronary artery leads to cardiomyocyte proliferation, but not maturation or hypertrophy (Giraud et al. 2006). In contrast, intact adrenal hormone signaling inhibits anemia-induced cardiomyocyte proliferation (Jonker et al. 2011b). The key to whether cortisol has a maturational effect on the heart may depend on the dose and resulting circulating levels. At higher levels that increase arterial pressure, and mimicking levels that would induce labor, exogenous cortisol induces cardiomyocyte enlargement (Lumbers et al. 2005). Maternal cortisol administration also causes cardiac enlargement in fetal sheep with minimal changes in fetal cortisol levels (Reini et al. 2008). This growth occurs via cellular proliferation, and can be blocked by intrapericardial administration of an MR blocker (Feng et al. 2013). Cortisol also induced apoptosis of cells of the cardiac conduction system through the GR. This picture of glucocorticoids inducing fetal cardiomyocyte proliferation through MR, and hypertrophy via increased arterial pressure, contrasts with findings in other mammals. In fetal mice, lack of cardiac glucocorticoid receptor leads to small hearts with small myocytes that are structurally immature (Rog-Zielinska et al. 2013), and in the pig at 80\% of gestation, maternal betamethasone administration reduces fetal cardiomyocyte proliferation while increasing terminal differentiation and apoptosis (Kim et al. 2014).

\section{Thyroid hormones}

Thyroid hormones are essential for normal fetal growth and maturation (Forhead \& Fowden 2014). Circulating thyroxine $\left(\mathrm{T}_{4}\right)$ continuously increases over the latter twothirds of gestation, reaching a peak and maintaining high levels (10-12 $\mu \mathrm{g} / \mathrm{dl}$ ) after birth (Polk 1995). The prepartum cortisol surge stimulates a similar surge in $\mathrm{T}_{3}$ by stimulating deiodination of $\mathrm{T}_{4}$ while inhibiting placental clearance of $\mathrm{T}_{3}$ (Liggins 1994, Forhead et al. 2006); $\mathrm{T}_{3}$ levels remain high (>300 ng/dl) after birth (Fig. 6; Polk 1995).

Ontogenetic changes in cardiac thyroid receptor (THR) concentrations have not been studied, to our knowledge, in the developing sheep heart. In rats, fetal

Published by Bioscientifica Ltd 


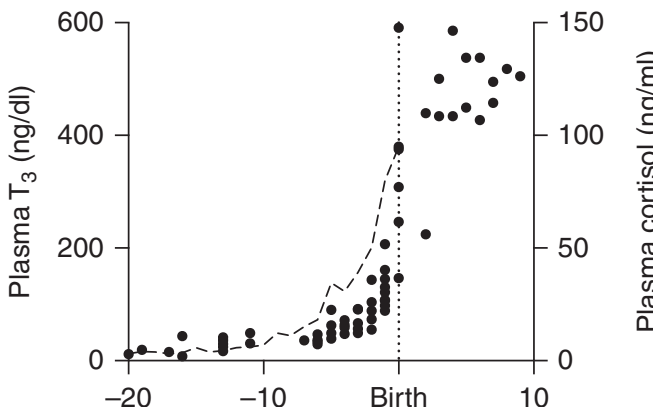

Figure 6

Circulating triiodothyronine $\left(\mathrm{T}_{3} ;\right.$ symbols) levels in normal fetal and newborn sheep expressed relative to the timing of birth; the prepartum $T_{3}$ surge is driven by the prepartum cortisol surge (dashed line, mean data from Fig. 5). Data from Klein et al. (1978) and Mathur et al. (1980).

$\mathrm{T}_{3}$ binding is similar in the nuclear extract of heart and liver (Perez-Castillo et al. 1985), and developmental liver and brain $\mathrm{T}_{3}$ binding profiles are similar between the rat and sheep (Polk et al. 1989). We hypothesize that, in the fetal sheep, cardiac THR follows the same developmental profile as liver THR: increasing slowly from mid-gestation and much more rapidly near term to levels maintained in the neonate and adult (Polk et al. 1989). Differential regulation of the isoforms is unclear; in rats, THRA mRNA expression is less than THRB (Strait et al. 1990), but THRA actively represses transcription of THRB via aporeceptor action in the fetal mouse heart (Mai et al. 2004).

Exogenous $\mathrm{T}_{3}$ reduces proliferation and increases terminal differentiation of near-term sheep cardiomyocytes in utero (Chattergoon et al. 2012a) and in culture (Chattergoon et al. 2007). Interestingly, thyroidectomy also reduces cell cycle activity (Chattergoon et al. 2012a, Segar et al. 2013); however, this reduction in cell cycle activity may not be solely due to reduced proliferation, because binucleation, which requires at least one last round of cell cycle activity for DNA replication, was also reduced. The proliferation-suppressing actions of $T_{3}$ can be observed in cardiomyocytes cultured from midgestation sheep, long before endogenous thyroid hormones increase and proliferation slows, but this effect in younger cardiomyocytes is not present in the rodent (Burton et al. 1999, Chattergoon et al. 2012b). Both $\mathrm{T}_{3}$ supplementation and thyroidectomy cause a small increase in cardiomyocyte size (Chattergoon et al. 2012a). Interestingly, $\mathrm{T}_{3}$ is required for the fetal sheep cardiac growth response to increased systolic stress imposed by pulmonary artery banding (Segar et al. 2013). This may be mediated by a lower heart rate reducing cardiac workload in the context of thyroidectomy, or $\mathrm{T}_{3}$ may be required in a permissive capacity. Adrenergic signaling may play a role, as $T_{3}$ regulates $\beta$-adrenergic receptors in fetal sheep (Padbury et al. 1986, Birk et al. 1992).

$\mathrm{T}_{3}$ clearly has the capacity to be a major regulator of terminal differentiation, but the timing of its rise (5 days prepartum; Fig. 6) in relation to terminal differentiation (initiated as early as 40 days prepartum, most rapid at 20 days prepartum; Fig. 2B; Jonker et al. 2015) calls into question its role in the normally-developing sheep heart. Its effect may be enhanced by a simultaneous rise in receptor levels, and the relief from aporeceptor actions provided with ligand binding. The in vivo regulation of terminal differentiation may be more nuanced. An intrinsic cell cycle timer ends proliferation of fetal cardiomyocytes in culture (Burton et al. 1999, Ball \& Levine 2005), but this arrest is reversible without addition of $\mathrm{T}_{3}$ (Burton et al. 1999). If also true in the sheep heart, this may imply that binucleation first appears during the reversible cell cycle arrest preceding true terminal differentiation. Further, one might wonder how exogenous $T_{3}$ can bring proliferation to an early conclusion if it depends on the cessation of proliferation via an intrinsic timer. The answer may be found in differences in cell cycle behavior in vitro versus in utero, or it may be the result of interspecies differences, with sheep cardiomyocytes more frequently withdrawing into $\mathrm{G}_{0}$ between proliferative cycles. Further experiments are required to determine the endogenous biological mechanisms, including $\mathrm{T}_{3}$, regulating terminal differentiation in the heart of the large mammal.

\section{Oxygen and metabolic substrates}

All metabolic substrates required for fetal growth and development must be obtained from the mother via the placenta. The placenta itself is a metabolic organ and thus disruptions in maternal supply or placental function impact the supply of oxygen, glucose and amino acids to the fetus. After birth, the supply of these substrates is no longer dependent on the placenta or (to an extent) the mother. Birth is associated with an immediate increase in partial pressure of oxygen in arterial blood from $\sim 25 \mathrm{~mm}$ $\mathrm{Hg}$ to more than $60 \mathrm{~mm} \mathrm{Hg}$ (Comline \& Silver 1972). Plasma glucose increases from $\sim 20 \mathrm{mg} / \mathrm{dl}(1.1 \mathrm{mmol} / \mathrm{l})$ to $40-60 \mathrm{mg} / \mathrm{dl}$ within minutes of birth; plasma free fatty acids increase fivefold in this same time $(<0.2-1.0 \mathrm{mEq} / \mathrm{l}$; Comline \& Silver 1972). These substrates are made available through the actions of catecholamines, cortisol, and thyroid hormone (Jones \& Ritchie 1978, Polk et al. 1987, Carstens et al. 1997, Fowden et al. 1998, Fowden

Published by Bioscientifica Ltd 
et al. 2001). Circulating levels of epinephrine and norepinephrine (Jones et al. 1983, Fowden et al. 1998), cortisol (Fig. 5), and thyroid hormone (Fig. 6) increase rapidly in the last 5-10 days before birth and remain high in the newborn period.

Most in utero studies on the regulatory role of oxygen on cardiomyocyte growth are achieved by experimental placental insufficiency and are complicated (or complemented) by simultaneous reductions in other metabolic substrates. Placental insufficiency induced by placental embolization is typically associated with only a transient increase in fetal arterial pressure, and leads to asymmetrical intrauterine growth restriction, with cardiac mass growth restriction that is nonetheless appropriate for body size. Proliferation and terminal differentiation are retarded in these hearts (Bubb et al. 2007, Louey et al. 2007). In some cases, intrauterine growth restriction may be associated with sustained fetal hypertension and cardiac hypertrophy (Murotsuki et al. 1997), although the mode of heart growth has not been studied. Hypoxia stimulates ANP synthesis and release (Chen 2005), which can inhibit fetal cardiomyocyte proliferation (O'Tierney et al. 2010a). This is potentially one mechanism of growth inhibition in the hypoxic fetal heart.

Fetal anemia is another method that has been used to study the role of oxygen on fetal cardiomyocyte growth. Although anemia reduces the oxygen carrying capacity but not oxygen partial pressure of the blood, it does stabilize HIF-1- $\alpha$ in the myocardium (Martin et al. 1998). The effect of fetal anemia is unlike that of intrauterine growth restriction associated with placental insufficiency. Chronically anemic fetuses have grossly enlarged hearts as a result of cardiomyocyte proliferation, maturation and cellular enlargement (Jonker et al. 2010).

Maternal nutrition has also been manipulated in order to determine what nutrient deprivation or excess does to fetal growth, although cardiomyocyte-specific measures have not been reported. In fetuses of nutrient-restricted ewes, somatic and heart growth are proportionally slowed (Dong et al. 2005, Dong et al. 2008). In fetuses of over-fed ewes, heart growth is proportional or accelerated relative to somatic growth (Dong et al. 2008, George et al. 2010, Fan et al. 2011). Although the cellular basis for these changes have not been reported, we speculate that the primary mechanism is through proliferation, because circulating fetal IGF1 levels are regulated by maternal feeding (Dong et al. 2005, Dong et al. 2008). It is noteworthy that over-nutrition is also associated with disturbed placental hemodynamics (Frias et al. 2011). Thus, the picture that emerges with regards to regulation of cardiac growth by oxygen and metabolic substrates in the fetus is complex.

\section{Arterial and venous pressure}

In the fetus, the ductus arteriosus permits the RV to eject blood into the aorta while the foramen ovale enables blood entering the right atrium to bypass the pulmonary circulation and directly fill the left atrium (Anderson et al. 1985). Because the placenta is responsible for fetal nutrient transfer and the lungs are unventilated, fetal pulmonary resistance is high and receives little of the RV output. After birth, the fetal vascular shunts close, leaving the RV to eject into the pulmonary circulation and the LV to eject into the systemic circulation. Fetal systemic arterial pressure increases slowly and heart rate decreases slowly with advancing gestation. The greatest change to perinatal hemodynamics occurs at birth, when systemic arterial pressure and heart rate suddenly rise and pulmonary artery pressure plummets (Fig. 7). These changes are driven by the closure of fetal vascular shunts, loss of the placenta (a large, low-resistance vascular bed), decreased pulmonary vascular resistance secondary to pulmonary ventilation, loss of lung water and oxygenation (Iwamoto et al. 1987), and resetting of the baroreflex.

Proliferation increases the cardiomyocyte number to an estimated 1.5-2.5 billion in the sheep LV just prior to birth (Fig. 2C; Burrell et al. 2003b, Jonker et al. 2015). Despite the higher wall stress of the RV in the fetus (due to a larger radius of curvature and thinner wall; Pinson et al. 1987), myocyte number in the RV free wall at the same age is only 1-1.5 billion (Fig. 2C; Jonker et al. 2015). The fibrous skeleton of the myocardium modifies its experience of wall stress, but although the collagen content of the immature heart is high relative to that of the adult (Marijianowski et al. 1994), there is no notable difference between the fetal ventricles (Jackson et al. 1993). It is interesting that the RV does not grow or remodel to normalize this relatively higher wall stress, although it does respond to experimentally elevated loads. Despite this apparent tolerance to higher wall stress, fetal RV myocytes are larger (Burrell et al. 2003b, Jonker et al. 2015), likely as a result of relatively increased load in either systole or diastole. No differences are noted in cell cycle activity or timing of terminal differentiation between the two ventricles.

Experimentally increased cardiac load stimulates growth of both the fetal LV and RV (Fishman et al. 1978, Segar et al. 1997, Barbera et al. 2000, Samson et al. 2000, Olson et al. 2006, Eghtesady et al. 2007, Jonker et al.

Published by Bioscientifica Ltd. 

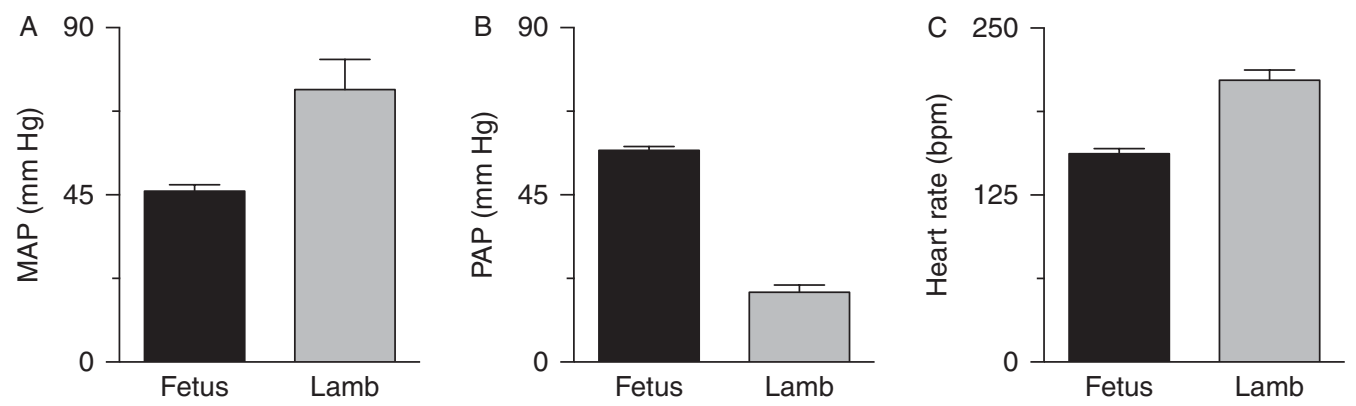

\section{Figure 7}

(A) Resting mean arterial pressure (MAP), (B) pulmonary arterial pressure (PAP), and (C) heart rate in normal fetal (118-142d GA, black) and newborn (2-28 days old, grey) sheep. Data from Black et al. (2002), Dawes et al.

2007b). Excessive LV systolic load from banding of the ascending aorta (fetal ventricular outflow banding restricts renal perfusion and is a high-AII model), initiated early in the second trimester, leads to either dilated ventricles with poor cardiac function and fetal hydrops or to very high LV systolic pressure generated by a grossly hypertrophic LV (Eghtesady et al. 2007). Third trimester aortic banding leads to compensated LV hypertrophy (Fishman et al. 1978, Samson et al. 2000). The immediate cardiomyocyte growth response to increased cardiac load (in a low-AII model) in the near-term fetus is increased cell cycle activity to increase the cell number (Jonker et al. 2007b). After about a week of aortic occlusion or plasma protein infusion (leading to fetal hypertension), however, robust cellular hypertrophy and terminal differentiation have become the predominant modes of growth (Barbera et al. 2000, Jonker et al. 2007b, Norris et al. 2014).

In contrast, reduced ventricular filling inhibits free wall growth, leading to dramatically smaller chamber volumes (Fishman et al. 1978). Reduced near-term fetal systemic arterial pressure similarly inhibits cardiomyocyte proliferation and cardiac growth (O'Tierney et al. 2010b, Norris et al. 2014). Increased preload in chronic fetal anemia may contribute to the increased cardiomyocyte proliferation, terminal differentiation and enlargement that lead to ventricular dilation and compensatory wall thickening (Jonker et al. 2010).

Many hormones can alter fetal hemodynamics, which must be considered when studying the influence of the hormone on fetal cardiac growth. For instance, AIIinduced fetal cardiac growth is dependent on its hypertensive effect (Sandgren et al. 2015), despite causing fetal sheep cardiomyocyte proliferation in culture (Sundgren et al. 2003c). Similarly, the effects of cortisol depend on the site of administration and fetal
(1980), Fineman et al. (1994), Iwamoto et al. (1987), Jaillard et al. (2001), Louey et al. (2000), Morin and Egan (1992) and Stahlman et al. (1967), data are mean \pm s.E.M.

hemodynamic effects (Lumbers et al. 2005, Giraud et al. 2006, Reini et al. 2008). Oddly, in one experiment phenylephrine increased blood pressure but did not cause heart growth (Segar et al. 2001). It is clear that fetal and postnatal cardiomyocytes are very sensitive to changes in ventricular wall stress and many endocrine perturbations alter cardiac load.

\section{Integration of experimental evidence}

Fetal cardiac growth patterns can be altered by in utero manipulation of endocrine, hemodynamic or nutritional factors (including oxygen), providing clues to underlying regulatory processes. These experiments have brought us to understand how in utero signals interact and establish precedence to regulate cardiomyocyte growth and maturation.

In experimental models, sustained increased systemic or pulmonary arterial pressure initially increases cellular proliferation, but leads ultimately to cardiomyocyte maturation and cellular hypertrophy (Barbera et al. 2000, Jonker et al. 2007b). This growth response, including gross cardiac hypertrophy and the maturational effect, is dependent on intact thyroid hormone signaling, despite low circulating levels (Sandgren et al. 2015). The curtailment of the proliferative response may be effected by the hypertension-induced rise in circulating ANP (Rosenfeld et al. 1992). In models in which increased cardiac load is imposed by placement of a constricting band on the main pulmonary artery or aorta, the renin-angiotensin system is activated. However, AII does not mediate the growthstimulating effects of fetal cardiac load (Segar et al. 1997, Segar et al. 2001, Jonker et al. 2007b, Sandgren et al. 2015). In fact, the growth-stimulating effects of AII in utero are mediated by AII-induced cardiac load (Sandgren et al.

Published by Bioscientifica Ltd. 
2015). Indeed, the cardiomyocyte enlargement and maturational response to cardiac load predominates in fetal sheep models in which arterial pressure is increased (Murotsuki et al. 1997, Lumbers et al. 2005).

The nutritional environment may trump endocrine regulators of cardiomyocyte growth. Increased circulating cortisol is a stereotypic response in oxygen- and nutrientrestricted fetuses. However, this is driven by a premature activation of the hypothalamic-pituitary-adrenal axis (Braems et al. 1996, Murotsuki et al. 1996), often resulting in preterm birth (Cock et al. 2001a), rather than elevation of baseline levels of cortisol. Regardless of when the placental insufficiency was initiated, elevated levels of cortisol are not routinely observed prior to 128dGA in placentallyrestricted fetuses (Gagnon et al. 1994, Murotsuki et al. 1996, Cock et al. 2001b, Louey et al. 2007). Cortisol is associated with the opposite effect in a low-nutrient versus normal intrauterine environment: proliferative growth, hypertrophic growth and maturation are all delayed or inhibited in placental insufficiency (although growth effects are manifest prior to differences in cortisol; Bubb et al. 2007, Louey et al. 2007, Morrison et al. 2007). Low IGF levels may mediate placental restriction's effects, but nutrients as substrate for growth may also be limiting. Alternatively, ANP is increased by acute and chronic anemic hypoxia (Silberbach et al. 1995, Chen 2005) and may mediate reduced proliferation, but it is unknown if ANP levels are sustained in chronic hypoxia stemming from placental insufficiency. Further, the inhibitory effect of ANP has only been shown to occur in the presence of exogenous stimulation of proliferation (O'Tierney et al. 2010a).

Cortisol is at the center of a web of interconnecting physiologic signals. At sub-pressor elevations of cortisol that resemble the levels from the early phase of the prepartum cortisol surge, cortisol stimulates cardiomyocyte proliferation (Giraud et al. 2006); these levels may not be sufficient to significantly increase $T_{3}$, but proliferation may be mediated via another effector such as AII (Forhead et al. 2000). Cortisol can increase fetal systemic arterial pressure via AII (Forhead et al. 2000), in which case the typical cardiomyocyte enlargement and maturation growth response to elevated cardiac load ensues (Lumbers et al. 2005). This higher level of cortisol also increases fetal $T_{3}$ levels (Sensky et al. 1994), which may suppress cardiomyocyte proliferation in the context of elevated pressure.

\section{Integration of normal development}

While experimental studies have helped us understand cardiomyocytes in stressed and suboptimal pregnancies, this knowledge has not translated easily into an understanding of how normal perinatal heart growth and maturation is regulated. Ontogenetically normal changes in endocrine, hemodynamic and nutritional factors are not necessarily correlated with cardiomyocyte growth and maturation outcomes that would be predicted by experimental studies (Fig. 8).

Altered fetal cortisol, $T_{3}$, oxygen and nutrients all modulate cardiac growth and maturation in utero. However, their roles (beyond permissive at normal levels) in normal perinatal cardiomyocyte growth and maturation remain unclear. The prepartum timing of the cortisol surge coincides with mass cardiomyocyte attrition (Fig. 8; Jonker et al. 2015). Cortisol administration to pregnant ewes leads to apoptosis of cardiomyocytes of the conduction system (Feng et al. 2013). Glucocorticoids have been shown to augment apoptosis in myocardial infarction (Mihailidou et al. 2009), and to cause calcium-mediated apoptosis in other cell types (Harr \& Distelhorst 2010), but little is known about this potential effect in fetal or neonatal cardiomyocytes. Cardiomyocyte enlargement accelerates 10 days before birth (Fig. 2E), also coinciding with the cortisol surge (Fig. 5). However, there is no experimental evidence that cortisol drives cardiomyocyte hypertrophy in the absence of simultaneous hypertension. $T_{3}$ clearly has a regulatory role in the immature cardiomyocyte. Both too little and excess hormone decrease cardiomyocyte cell cycle activity, but have differential effects on terminal differentiation depending on gestational age (Chattergoon et al. 2012a). The role in normal maturation may be more subtle; the steepest increase in binucleation rate is largely completed prior to the prepartum $\mathrm{T}_{3}$ surge. On the other hand, although the number of mononucleated myocytes in the neonatal heart is very low (in both absolute number and relative proportion), this population generates relatively more binucleated cells than in the fetus, consistent with increased neonatal $\mathrm{T}_{3}$ levels (Fig. 8). In the fetus, oxygen and nutrient restriction limits cardiac growth and maturation. There is no evidence, however, to suggest that increases in oxygen with ventilation and changes in circulating nutrients following birth and with oral feeding drive increased cardiac growth in the neonate.

Better evidence, perhaps, supports the roles of IGF1, AII and arterial pressure in normal cardiac growth and maturation in utero. Changed cardiac load drives the type of cardiomyocyte growth in both fetuses (summarized above) and adults (Carabello 2002). This is so much so, that endocrine influences on prenatal cardiac growth can be predicted by their effect on arterial pressure. In the

Published by Bioscientifica Ltd. 


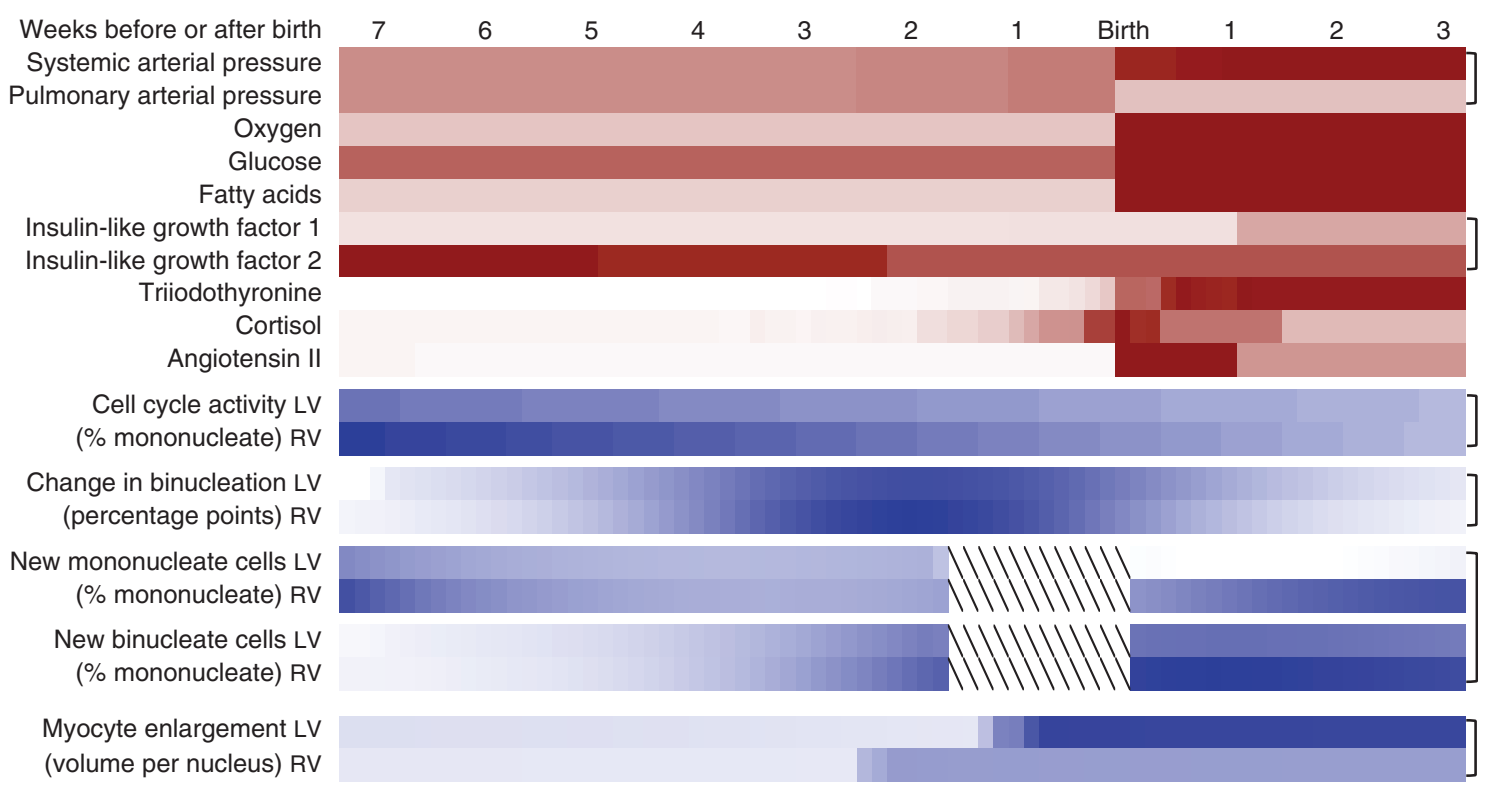

\section{Figure 8}

Overview of growth-regulating factors (red) and cardiomyocyte growth kinetics (blue) in the perinatal sheep heart. Proliferation and maturation are expressed to emphasize changing rates of growth processes in the LV and RV, rather than the accumulated outcome of these processes, and how these kinetics might relate to changing endocrine and other physiological modulators of growth. Daily number of new mononucleated and binucleated myocytes are shown normalized to mononucleated cell number (because these are the cells that enter the cell cycle to proliferate or terminally differentiate). Myocyte volume enlargement is expressed

fetus, systemic and pulmonary arterial are similar. It is notable that, after birth, there are dramatic but opposite changes in arterial pressures of the systemic circulation (rises) and pulmonary circulation (decreases), but the rate of cardiomyocyte enlargement is accelerated in both ventricles compared to before birth (Fig. 8). Continued proliferation in the RV may be explained if low pulmonary arterial pressure is permissive, while sustained elevation in systemic arterial pressure inhibits LV cardiomyocyte proliferation. Increasing levels of IGF1 may support cardiomyocyte proliferation through birth. Increased systemic arterial pressure may inhibit IGF1-stimulated proliferation in the neonatal LV, while lower pulmonary arterial pressure permits proliferation in the RV (Fig. 8). Alternatively, it is unknown in sheep whether IGF1 is a mitogen or stimulates cardiomyocyte enlargement after birth, as occurs for IGF2 in the developing rat (Liu et al. 1996). The prepartum decline in AII correlates with the increase in cardiomyocyte terminal differentiation (Fig. 8), although the maturational effect of AII appears experimentally to be mediated through increased arterial pressure. Similar to IGF1, the tremendous increase in AII at relative to nuclear number because DNA content appears to critically mediate magnitude of hypertrophic response in cardiomyocytes. Each parameter is expressed as a monochrome heat map (light $=$ low, dark = high) and is derived from data described in this manuscript. Related data sets (bracketed) share a saturation scale and are comparable across rows. The values within the hatched area cannot be estimated because, while proliferation and terminal differentiation almost certainly continue, cell number declines in this period.

birth is concomitant with a doubling of systemic arterial pressure and dramatic decline in pulmonary arterial pressure, which may explain dimorphic ventricular growth patterns in this same period (Fig. 8). Thus, AII may (alternatively to IGF1) drive proliferation in the low-load RV, but be inhibited from similar action in the high-load LV.

\section{Intracellular integration of regulatory signals}

The intracellular signaling pathways activated by endocrine and physiologic signals in the fetal ovine heart are beyond the scope of this review. Many intracellular proteins have been identified as contributing to regulation of cardiomyocyte growth and maturation (some topics reviewed in Heineke \& Molkentin (2006) and Oyama et al. (2014)); much of this work has been accomplished in the rodent. It is clear that stable withdrawal from the cell cycle can be overcome by over-expression or knockout of many genes (Poolman et al. 1999, Chaudhry et al. 2004, Heber-Katz et al. 2004, Li et al. 2008). These regulatory elements, and those contributing to other aspects of

Published by Bioscientifica Ltd 
cardiomyocyte growth, are legitimately identified as regulating cardiomyocyte endowment and morphology, and thus lifelong health. However, current approaches have failed to yield an understanding of how these elements are integrated and prioritized to generate specific cellular outcomes. Perhaps new approaches, such as interactome network analysis, will lead to a more comprehensive understanding (Menche et al. 2015). Indeed, transcriptomic modeling has recently identified discrete regulatory patterns in the ovine heart between 130 days of gestation, term and 14 days after birth, which may shed light on how intracellular processes interact to determine cardiomyocyte growth and maturation (Richards et al. 2015).

\section{Conclusion}

There are substantial disparities between perinatal changes in endocrine factors and the timing of cardiomyocyte growth and maturation. A number of gaps remain in our knowledge about the regulation of growth and maturation in perinatal ovine cardiomyocytes. First, what is the stimulus for and consequence of mass cardiomyocyte attrition in the perinatal heart? It could be deliberate remodeling, as previously proposed, or perhaps its role is to eliminate most proliferative cardiomyocytes as part of the tight cell cycle control evidenced in the postnatal heart. Secondly, can neonatal cardiomyocytes be stimulated to proliferate? Myocyte number continues to increase slowly in the neonatal RV, suggesting that if ventricular load is minimized, proliferation may be permitted. On the other hand, new evidence suggests a burst of cardiomyocyte generation in adolescence: which cells participate and what regulates their proliferation? Thirdly, what drives accelerated RV cardiomyocyte enlargement in the neonate, given low pulmonary arterial pressure? All experimental evidence suggests that cardiac load is the strongest growth modulator in the heart. Fourthly, whether terminal differentiation occurs and can be detected prior to binucleation is a problem limiting current research. Finally, our understanding of the intrinsic differences between fetal $\mathrm{LV}$ and $\mathrm{RV}$ cardiomyocytes is lacking. There are clear divergences in growth trajectories that begin in utero and set the stage for cardiac function after birth.

\section{Declaration of interest}

The authors declare that there is no conflict of interest that could be perceived as prejudicing the impartiality of this review.

\section{Funding}

Research reported in this review was supported by the Eunice Kennedy Shriver National Institute of Child Health and Human Development of the National Institutes of Health under award numbers R01HD071068 and P01HD034430. The content is solely the responsibility of the authors and does not necessarily represent the official views of the National Institutes of Health.

\section{Acknowledgements}

The authors would like to acknowledge the advice and editorial comments from George Giraud, Fred Tibayan, Jeffrey Segar and, in particular, Debra Anderson.

\section{References}

Adler CP 1975 Relationship between deoxyribonucleic acid content and nucleoli in human heart muscle cells and estimation of cell number during cardiac growth and hyperfunction. Recent Advances in Studies on Cardiac Structure and Metabolism 8 373-386.

Adler CP \& Costabel U 1975 Cell number in human heart in atrophy, hypertrophy, and under the influence of cytostatics. Recent Advances in Studies on Cardiac Structure and Metabolism 6 343-355.

Adler CP \& Costabel U 1980 Myocardial DNA and cell number under the influence of cytostatics. I. Post mortem investigations of human hearts. Virchows Archiv. B, Cell Pathology Including Molecular Pathology 32 109-125. (doi:10.1007/BF02889020)

Adler CP, Friedburg H, Herget GW, Neuburger M \& Schwalb H 1996 Variability of cardiomyocyte DNA content, ploidy level and nuclear number in mammalian hearts. Virchows Archiv 429 159-164.

Anderson DF, Faber JJ, Morton MJ, Parks CM, Pinson CW \& Thornburg KL 1985 Flow through the foramen ovale of the fetal and new-born lamb. Journal of Physiology 365 29-40. (doi:10.1113/jphysiol.1985.sp015757)

Anderson DF, Barbera A \& Faber JJ 1994 Substantial reductions in blood pressure after bilateral nephrectomy in fetal sheep. American Journal of Physiology 266 H17-H20.

Back SA, Riddle A \& Hohimer AR 2006 Role of instrumented fetal sheep preparations in defining the pathogenesis of human periventricular white-matter injury. Journal of Child Neurology 21 582-589. (doi:10.1177/08830738060210070101)

Bae S, Xiao Y, Li G, Casiano CA \& Zhang L 2003 Effect of maternal chronic hypoxic exposure during gestation on apoptosis in fetal rat heart. American Journal of Physiology. Heart and Circulatory Physiology 285 H983-H990. (doi:10.1152/ajpheart.00005.2003)

Ball AJ \& Levine F 2005 Telomere-independent cellular senescence in human fetal cardiomyocytes. Aging Cell 4 21-30. (doi:10.1111/j.14749728.2004.00137.x)

Barbera A, Giraud GD, Reller MD, Maylie J, Morton MJ \& Thornburg KL 2000 Right ventricular systolic pressure load alters myocyte maturation in fetal sheep. American Journal of Physiology. Regulatory, Integrative and Comparative Physiology 279 R1157-R1164.

Barry JS \& Anthony RV 2008 The pregnant sheep as a model for human pregnancy. Theriogenology 69 55-67. (doi:10.1016/j.theriogenology. 2007.09.021)

Baxter RC 2014 IGF binding proteins in cancer: mechanistic and clinical insights. Nature Reviews. Cancer 14 329-341. (doi:10.1038/nrc3720)

Bensley JG, Stacy VK, De Matteo R, Harding R \& Black MJ 2010 Cardiac remodelling as a result of pre-term birth: implications for future cardiovascular disease. European Heart Journal 31 2058-2066. (doi:10.1093/eurheartj/ehq104)

Bers DM 2002 Cardiac excitation-contraction coupling. Nature $\mathbf{4 1 5}$ 198-205. (doi:10.1038/415198a)

Published by Bioscientifica Ltd 
Birk E, Tyndall MR, Erickson LC, Rudolph AM \& Roberts JM 1992 Effects of thyroid hormone on myocardial adrenergic $\beta$-receptor responsiveness and function during late gestation. Pediatric Research 31 468-473. (doi:10.1203/00006450-199205000-00011)

Bishop SP \& Hine P 1975 Cardiac muscle cytoplasmic and nuclear development during canine neonatal growth. Recent Advances in Studies on Cardiac Structure and Metabolism 8 77-98.

Black SM, Bekker JM, McMullan DM, Parry AJ, Ovadia B, Reinhartz O, Lakshminrushimha S, Mata-Greenwood E, Steinhorn RH \& Fineman JR 2002 Alterations in nitric oxide production in 8-week-old lambs with increased pulmonary blood flow. Pediatric Research 52 233-244. (doi:10.1203/00006450-200208000-00016)

Braems GA, Matthews SG \& Challis JR 1996 Differential regulation of proopiomelanocortin messenger ribonucleic acid in the pars distalis and pars intermedia of the pituitary gland after prolonged hypoxemia in fetal sheep. Endocrinology 137 2731-2738. (doi:10.1210/endo.137.7. 8770892)

Brodsky V, Sarkisov DS, Arefyeva AM, Panova NW \& Gvasava IG 1994 Polyploidy in cardiac myocytes of normal and hypertrophic human hearts; range of values. Virchows Archiv 424 429-435. (doi:10.1007/ BF00190566)

Brook WH, Connell S, Cannata J, Maloney JE \& Walker AM 1983 Ultrastructure of the myocardium during development from early fetal life to adult life in sheep. Journal of Anatomy 137 729-741.

Broughton Pipkin F, Lumbers ER \& Mott JC 1974 Factors influencing plasma renin and angiotensin II in the conscious pregnant ewe and its foetus. Journal of Physiology 243 619-636. (doi:10.1113/jphysiol.1974. sp010769)

Brown LD 2014 Endocrine regulation of fetal skeletal muscle growth: impact on future metabolic health. Journal of Endocrinology 221 R13-R29. (doi:10.1530/JOE-13-0567)

Bubb KJ, Cock ML, Black MJ, Dodic M, Boon WM, Parkington HC, Harding R \& Tare M 2007 Intrauterine growth restriction delays cardiomyocyte maturation and alters coronary artery function in the fetal sheep. Journal of Physiology 578 871-881. (doi:10.1113/jphysiol.2006.121160)

Burrell JH, Boyn AM, Kumarasamy V, Hsieh A, Head SI \& Lumbers ER $2003 a$ Growth and maturation of cardiac myocytes in fetal sheep in the second half of gestation. Anatomical Record. Part A, Discoveries in Molecular, Cellular, and Evolutionary Biology 274 952-961. (doi:10.1002/ar.a.10110)

Burrell JH, Boyn AM, Kumarasamy V, Hsieh A, Head SI \& Lumbers ER 2003b Growth and maturation of cardiac myocytes in fetal sheep in the second half of gestation. Anatomical Record 274 952-961. (doi:10.1002/ ar.a.10110)

Burrell JH, Hegarty BD, McMullen JR \& Lumbers ER 2001 Effects of gestation on ovine fetal and maternal angiotensin receptor subtypes in the heart and major blood vessels. Experimental Physiology 86 71-82. (doi:10.1113/eph8602075)

Burton PB, Raff MC, Kerr P, Yacoub MH \& Barton PJ 1999 An intrinsic timer that controls cell-cycle withdrawal in cultured cardiac myocytes. Developmental Biology 216 659-670. (doi:10.1006/dbio.1999.9524)

Caldarone CA, Barner EW, Wang L, Karimi M, Mascio CE, Hammel JM, Segar JL, Du C \& Scholz TD 2004 Apoptosis-related mitochondrial dysfunction in the early postoperative neonatal lamb heart. Annals of Thoracic Surgery 78 948-955. (doi:10.1016/j.athoracsur.2004.04.031)

Carabello BA 2002 Concentric versus eccentric remodeling. Journal of Cardiac Failure 8 S258-S263. (doi:10.1054/jcaf.2002.129250)

Carr JM, Owens JA, Grant PA, Walton PE, Owens PC \& Wallace JC 1995 Circulating insulin-like growth factors (IGFs), IGF-binding proteins (IGFBPs) and tissue mRNA levels of IGFBP-2 and IGFBP-4 in the ovine fetus. Journal of Endocrinology 145 545-557. (doi:10.1677/joe.0. 1450545)

Carstens GE, Mostyn PM, Lammoglia MA, Vann RC, Apter RC \& Randel RD 1997 Genotypic effects on norepinephrine-induced changes in thermogenesis, metabolic hormones, and metabolites in newborn calves. Journal of Animal Science 75 1746-1755.
Carter AM 2007 Animal models of human placentation - a review. Placenta 28(Suppl A) S41-S47. (doi:10.1016/j.placenta.2006.11.002)

Challis JRG, Matthews SG, Gibb W \& Lye SJ 2000 Endocrine and paracrine regulation of birth at term and preterm. Endocrine Reviews 21 514-550. (doi:10.1210/edrv.21.5.0407)

Chattergoon NN, Giraud GD \& Thornburg KL 2007 Thyroid hormone inhibits proliferation of fetal cardiac myocytes in vitro. Journal of Endocrinology 192 R1-R8. (doi:10.1677/JOE-06-0114)

Chattergoon NN, Giraud GD, Louey S, Stork P, Fowden AL \& Thornburg KL $2012 a$ Thyroid hormone drives fetal cardiomyocyte maturation. FASEB Journal 26 397-408. (doi:10.1096/fj.10-179895)

Chattergoon NN, Louey S, Stork P, Giraud GD \& Thornburg KL $2012 b$ Midgestation ovine cardiomyocytes are vulnerable to mitotic suppression by thyroid hormone. Reproductive Sciences 19 642-649. (doi:10.1177/ 1933719111432860)

Chattergoon NN, Louey S, Stork PJ, Giraud GD \& Thornburg KL 2014 Unexpected maturation of PI3K and MAPK-ERK signaling in fetal ovine cardiomyocytes. American Journal of Physiology. Heart and Circulatory Physiology 307 H1216-H1225. (doi:10.1152/ajpheart.00833.2013)

Chaudhry HW, Dashoush NH, Tang H, Zhang L, Wang X, Wu EX \& Wolgemuth DJ 2004 Cyclin A2 mediates cardiomyocyte mitosis in the postmitotic myocardium. Journal of Biological Chemistry 279 35858-35866. (doi:10.1074/jbc.M404975200)

Chen YF 2005 Atrial natriuretic peptide in hypoxia. Peptides 26 1068-1077. (doi:10.1016/j.peptides.2004.08.030)

Cheng W, Reiss K, Kajstura J, Kowal K, Quaini F \& Anversa P 1995 Down-regulation of the IGF-1 system parallels the attenuation in the proliferative capacity of rat ventricular myocytes during postnatal development. Laboratory Investigation 72 646-655.

Cheung CY, Johnson DD \& Reyes V 1996 Ontogeny of insulin-like growth factor-I and -II gene expression in ovine fetal heart. Journal of the Society for Gynecologic Investigation 3 309-315. (doi:10.1016/S10715576(96)00038-X)

Clubb FJ Jr \& Bishop SP 1984 Formation of binucleated myocardial cells in the neonatal rat. An index for growth hypertrophy. Laboratory Investigation $50571-577$.

Cock M, Camm E, Louey S, Joyce B \& Harding R 2001a Postnatal outcomes in term and preterm lambs following fetal growth restriction. Clinical and Experimental Pharmacology \& Physiology 28 931-937. (doi:10.1046/j. 1440-1681.2001.03552.x)

Cock ML, Albuquerque CA, Joyce BJ, Hooper SB \& Harding R $2001 b$ Effects of intrauterine growth restriction on lung liquid dynamics and lung development in fetal sheep. American Journal of Obstetrics and Gynecology 184 209-216. (doi:10.1067/mob.2001.108858)

Comline RS \& Silver M 1972 The composition of foetal and maternal blood during parturition in the ewe. Journal of Physiology 222 233-256. (doi:10.1113/jphysiol.1972.sp009795)

Crespi EJ, Steckler TL, Mohankumar PS \& Padmanabhan V 2006 Prenatal exposure to excess testosterone modifies the developmental trajectory of the insulin-like growth factor system in female sheep. Journal of Physiology 572 119-130. (doi:10.1113/jphysiol.2005.103929)

Dawes GS, Johnston BM \& Walker DW 1980 Relationship of arterial pressure and heart rate in fetal, new-born and adult sheep. Journal of Physiology 309 405-417. (doi:10.1113/jphysiol.1980.sp013516)

Dong F, Ford SP, Fang CX, Nijland MJ, Nathanielsz PW \& Ren J 2005 Maternal nutrient restriction during early to mid gestation up-regulates cardiac insulin-like growth factor (IGF) receptors associated with enlarged ventricular size in fetal sheep. Growth Hormone \& IGF Research 15 291-299. (doi:10.1016/j.ghir.2005.05.003)

Dong F, Ford SP, Nijland MJ, Nathanielsz PW \& Ren J 2008 Influence of maternal undernutrition and overfeeding on cardiac ciliary neurotrophic factor receptor and ventricular size in fetal sheep. Journal of Nutritional Biochemistry 19 409-414. (doi:10.1016/j.jnutbio. 2007.06.003)

Eghtesady P, Michelfelder E, Altaye M, Ballard E, Hirsh R \& Beekman RH III 2007 Revisiting animal models of aortic stenosis in the early gestation

Published by Bioscientifica Ltd. 
fetus. Annals of Thoracic Surgery 83 631-639. (doi:10.1016/j.athoracsur. 2006.09.043)

Faber JJ, Anderson DF, Louey S, Thornburg KL \& Giraud GD 2011 Insignificant response of the fetal placental circulation to arterial hypotension in sheep. Journal of Applied Physiology 111 1042-1047. (doi:10.1152/japplphysiol.00345.2011)

Fan X, Turdi S, Ford SP, Hua Y, Nijland MJ, Zhu M, Nathanielsz PW \& Ren J 2011 Influence of gestational overfeeding on cardiac morphometry and hypertrophic protein markers in fetal sheep. Journal of Nutritional Biochemistry 22 30-37. (doi:10.1016/j.jnutbio.2009.11.006)

Feng X, Reini SA, Richards E, Wood CE \& Keller-Wood M 2013 Cortisol stimulates proliferation and apoptosis in the late gestation fetal heart: differential effects of mineralocorticoid and glucocorticoid receptors. American Journal of Physiology. Regulatory, Integrative and Comparative Physiology 305 R343-R350. (doi:10.1152/ajpregu.00112.2013)

Fernandez E, Siddiquee Z \& Shohet RV 2001 Apoptosis and proliferation in the neonatal murine heart. Developmental Dynamics 221 302-310. (doi:10.1002/dvdy.1139)

Fineman JR, Wong J, Morin FC III, Wild LM \& Soifer SJ 1994 Chronic nitric oxide inhibition in utero produces persistent pulmonary hypertension in newborn lambs. Journal of Clinical Investigation 93 2675-2683. (doi:10.1172/JCI117281)

Fishman NH, Hof RB, Rudolph AM \& Heymann MA 1978 Models of congenital heart disease in fetal lambs. Circulation 58 354-364. (doi:10.1161/01.CIR.58.2.354)

Fleischman AR, Oakes GK, Epstein MF, Catt KJ \& Chez RA 1975 Plasma renin activity during ovine pregnancy. American Journal of Physiology 228 901-904

Forhead AJ, Broughton Pipkin F \& Fowden AL 2000 Effect of cortisol on blood pressure and the renin-angiotensin system in fetal sheep during late gestation. Journal of Physiology 526 167-176. (doi:10.1111/j.14697793.2000.00167.x)

Forhead AJ, Curtis K, Kaptein E, Visser TJ \& Fowden AL 2006 Developmental control of iodothyronine deiodinases by cortisol in the ovine fetus and placenta near term. Endocrinology 147 5988-5994. (doi:10.1210/en.2006-0712)

Forhead AJ \& Fowden AL 2014 Thyroid hormones in fetal growth and prepartum maturation. Journal of Endocrinology 221 R87-R103. (doi:10.1530/JOE-14-0025)

Forsgren S \& Thornell LE 1981 The development of Purkinje fibres and ordinary myocytes in the bovine fetal heart. An ultrastructural study. Anatomy and Embryology 162 127-136. (doi:10.1007/BF00306485)

Fowden AL 2003 The insulin-like growth factors and feto-placental growth. Placenta 24 803-812. (doi:10.1016/S0143-4004(03)00080-8)

Fowden AL, Mundy L \& Silver M 1998 Developmental regulation of glucogenesis in the sheep fetus during late gestation. Journal of Physiology 508 937-947. (doi:10.1111/j.1469-7793.1998.937bp.x)

Fowden AL, Mapstone J \& Forhead AJ 2001 Regulation of glucogenesis by thyroid hormones in fetal sheep during late gestation. Journal of Endocrinology 170 461-469. (doi:10.1677/joe.0.1700461)

Frias AE, Morgan TK, Evans AE, Rasanen J, Oh KY, Thornburg KL \& Grove KL 2011 Maternal high-fat diet disturbs uteroplacental hemodynamics and increases the frequency of stillbirth in a nonhuman primate model of excess nutrition. Endocrinology 152 2456-2464. (doi:10.1210/en.2010-1332)

Gagnon R, Challis J, Johnston L \& Fraher L 1994 Fetal endocrine responses to chronic placental embolization in the late-gestation ovine fetus. American Journal of Obstetrics and Gynecology 170 929-938. (doi:10.1016/S0002-9378(94)70309-4)

Gardner DS, Buttery PJ, Daniel Z \& Symonds ME 2007 Factors affecting birth weight in sheep: maternal environment. Reproduction 133 297-307. (doi:10.1530/REP-06-0042)

George LA, Uthlaut AB, Long NM, Zhang L, Ma Y, Smith DT, Nathanielsz PW \& Ford SP 2010 Different levels of overnutrition and weight gain during pregnancy have differential effects on fetal growth and organ development. Reproductive Biology and Endocrinology 875. (doi:10.1186/1477-7827-8-75)

Gimonet V, Bussieres L, Medjebeur AA, Gasser B, Lelongt B \& Laborde K 1998 Nephrogenesis and angiotensin II receptor subtypes gene expression in the fetal lamb. American Journal of Physiology 274 F1062-F1069.

Giraud GD, Louey S, Jonker S, Schultz J \& Thornburg KL 2006 Cortisol stimulates cell cycle activity in the cardiomyocyte of the sheep fetus. Endocrinology 147 3643-3649. (doi:10.1210/en.2006-0061)

Hammel JM, Caldarone CA, Van Natta TL, Wang LX, Welke KF, Li W, Niles S, Barner E, Scholz TD, Behrendt DM et al. 2003 Myocardial apoptosis after cardioplegic arrest in the neonatal lamb. Journal of Thoracic and Cardiovascular Surgery 125 1268-1275. (doi:10.1016/ S0022-5223(02)73238-8)

Hantzis V, Albiston A, Matsacos D, Wintour EM, Peers A, Koukoulas I, Myles K, Moritz K \& Dodic M 2002 Effect of early glucocorticoid treatment on MR and GR in late gestation ovine kidney. Kidney International 61 405-413. (doi:10.1046/j.1523-1755. 2002.00157.x)

Harr MW \& Distelhorst CW 2010 Apoptosis and autophagy: decoding calcium signals that mediate life or death. Cold Spring Harbor Symposia on Quantitative Biology 2 a005579. (doi:10.1101/cshperspect.a005579)

Heber-Katz E, Leferovich J, Bedelbaeva K, Gourevitch D \& Clark L 2004 The scarless heart and the MRL mouse. Philosophical Transactions of the Royal Society of London. Series B, Biological sciences 359 785-793. (doi:10.1098/ rstb.2004.1468)

Heineke J \& Molkentin JD 2006 Regulation of cardiac hypertrophy by intracellular signalling pathways. Nature Reviews. Molecular Cell Biology 7 589-600. (doi:10.1038/nrm1983)

Hinchliffe SA, Lynch MR, Sargent PH, Howard CV \& Van Velzen D 1992 The effect of intrauterine growth retardation on the development of renal nephrons. British Journal of Obstetrics and Gynaecology 99 296-301. (doi:10.1111/j.1471-0528.1992.tb13726.x)

Holley DG, Martin GR, Brenner JI, Fyfe DA, Huhta JC, Kleinman CS, Ritter SB \& Silverman NH 1995 Diagnosis and management of fetal cardiac tumors: a multicenter experience and review of published reports. Journal of the American College of Cardiology 26 516-520. (doi:10.1016/0735-1097(95)80031-B)

Huttenbach Y, Ostrowski ML, Thaller D \& Kim HS 2001 Cell proliferation in the growing human heart: MIB-1 immunostaining in preterm and term infants at autopsy. Cardiovascular Pathology 10 119-123. (doi:10.1016/ S1054-8807(01)00065-5)

Iwamoto HS, Teitel D \& Rudolph AM 1987 Effects of birth-related events on blood flow distribution. Pediatric Research 22 634-640. (doi:10.1203/ 00006450-198712000-00004)

Jackson M, Connell MG \& Smith A 1993 Development of the collagen network of the human fetal myocardium: an immunohistochemical study. International Journal of Cardiology 41 77-86. (doi:10.1016/01675273(93)90139-8)

Jaillard S, Houfflin-Debarge V, Riou Y, Rakza T, Klosowski S, Lequien P \& Storme L 2001 Effects of catecholamines on the pulmonary circulation in the ovine fetus. American Journal of Physiology. Regulatory, Integrative and Comparative Physiology 281 R607-R614.

Jones CT \& Ritchie JW 1978 The metabolic and endocrine effects of circulating catecholamines in fetal sheep. Journal of Physiology $\mathbf{2 8 5}$ 395-408. (doi:10.1113/jphysiol.1978.sp012578)

Jones CM III, Meis PJ, Rose JC \& Greiss FC Jr 1983 Subhourly variability of circulating norepinephrine and epinephrine in the pregnant ewe and fetal and newborn lamb. American Journal of Obstetrics and Gynecology 147 121-124.

Jonker SS, Zhang L, Louey S, Giraud GD, Thornburg KL \& Faber JJ 2007a Myocyte enlargement, differentiation, and proliferation kinetics in the fetal sheep heart. Journal of Applied Physiology 102 1130-1142. (doi:10.1152/japplphysiol.00937.2006)

Jonker SS, Faber JJ, Anderson DF, Thornburg KL, Louey S \& Giraud GD $2007 b$ Sequential growth of fetal sheep cardiac myocytes in response to 
simultaneous arterial and venous hypertension. American Journal of Physiology. Regulatory, Integrative and Comparative Physiology 292 R913-R919. (doi:10.1152/ajpregu.00484.2006)

Jonker SS, Giraud MK, Giraud GD, Chattergoon NN, Louey S, Davis LE, Faber JJ \& Thornburg KL 2010 Cardiomyocyte enlargement, proliferation and maturation during chronic fetal anaemia in sheep. Experimental Physiology 95 131-139. (doi:10.1113/expphysiol.2009. 049379)

Jonker SS, Scholz TD \& Segar JL 2011a Transfusion effects on cardiomyocyte growth and proliferation in fetal sheep after chronic anemia. Pediatric Research 69 485-490. (doi:10.1203/PDR.0b013e3182181e01)

Jonker SS, Scholz TD \& Segar JL $2011 b$ The effect of adrenalectomy on the cardiac response to subacute fetal anemia. Canadian Journal of Physiology and Pharmacology 89 79-88. (doi:10.1139/Y10-108)

Jonker SS, Louey S, Giraud GD, Thornburg KL \& Faber JJ 2015 Timing of cardiomyocyte growth, maturation, and attrition in perinatal sheep. FASEB Journal 29 4346-4357. (doi:10.1096/fj.15-272013)

Joyce BJ, Louey S, Davey MG, Cock ML, Hooper SB \& Harding R 2001 Compromised respiratory function in postnatal lambs after placental insufficiency and intrauterine growth restriction. Pediatric Research 50 641-649. (doi:10.1203/00006450-200111000-00018)

Kajstura J, Mansukhani M, Cheng W, Reiss K, Krajewski S, Reed JC, Quaini F, Sonnenblick EH \& Anversa P 1995 Programmed cell death and expression of the protooncogene bcl-2 in myocytes during postnatal maturation of the heart. Experimental Cell Research 219 110-121. (doi:10.1006/excr.1995.1211)

Karimi M, Wang LX, Hammel JM, Mascio CE, Abdulhamid M, Barner EW, Scholz TD, Segar JL, Li WG, Niles SD et al. 2004 Neonatal vulnerability to ischemia and reperfusion: Cardioplegic arrest causes greater myocardial apoptosis in neonatal lambs than in mature lambs. Journal of Thoracic and Cardiovascular Surgery 127 490-497. (doi:10.1016/j.jtcvs.2003.07.052)

Kim HD, Kim DJ, Lee IJ, Rah BJ, Sawa Y \& Schaper J 1992 Human fetal heart development after mid-term: morphometry and ultrastructural study. Journal of Molecular and Cellular Cardiology 24 949-965. (doi:10.1016/ 0022-2828(92)91862-Y)

Kim MY, Eiby YA, Lumbers ER, Wright LL, Gibson KJ, Barnett AC \& Lingwood BE 2014 Effects of glucocorticoid exposure on growth and structural maturation of the heart of the preterm piglet. PLOS ONE 9 e93407. (doi:10.1371/journal.pone.0093407)

Klein AH, Oddie TH \& Fisher DA 1978 Effect of parturition on serum iodothyronine concentrations in fetal sheep. Endocrinology 103 1453-1457. (doi:10.1210/endo-103-4-1453)

Kramer CM, Rogers WJ, Park CS, Seibel PS, Shaffer A, Theobald TM, Reichek N, Onodera T \& Gerdes AM 1998 Regional myocyte hypertrophy parallels regional myocardial dysfunction during post-infarct remodeling. Journal of Molecular and Cellular Cardiology 30 1773-1778. (doi:10.1006/jmcc.1998.0741)

Laflamme MA \& Murry CE 2011 Heart regeneration. Nature 473 326-335. (doi:10.1038/nature10147)

Lam KY, Dickens P \& Chan AC 1993 Tumors of the heart. A 20-year experience with a review of 12,485 consecutive autopsies. Archives of Pathology \& Laboratory Medicine 117 1027-1031.

Legato MJ 1979 Cellular mechanisms of normal growth in the mammalian heart. I. Qualitative and quantitative features of ventricular architecture in the dog from birth to five months of age. Circulation Research $\mathbf{4 4}$ 250-262. (doi:10.1161/01.RES.44.2.250)

Levkau B, Schafers M, Wohlschlaeger J, von Wnuck Lipinski K, Keul P, Hermann S, Kawaguchi N, Kirchhof P, Fabritz L, Stypmann J et al. 2008 Survivin determines cardiac function by controlling total cardiomyocyte number. Circulation 117 1583-1593. (doi:10.1161/CIRCULATIONAHA.107.734160)

Li M, Naqvi N, Yahiro E, Liu K, Powell PC, Bradley WE, Martin DI, Graham RM, Dell'Italia LJ \& Husain A 2008 c-kit is required for cardiomyocyte terminal differentiation. Circulation Research 102 677-685. (doi:10.1161/CIRCRESAHA.107.161737) Printed in Great Britain
Liggins GC 1968 Premature parturition after infusion of corticotrophin or cortisol into foetal lambs. Journal of Endocrinology 42 323-329. (doi:10.1677/joe.0.0420323)

Liggins GC 1994 The role of cortisol in preparing the fetus for birth. Reproduction, Fertility, and Development 6 141-150. (doi:10.1071/ RD9940141)

van der Linden DS, Sciascia Q, Sales F \& McCoard SA 2013 Placental nutrient transport is affected by pregnancy rank in sheep. Journal of Animal Science 91 644-653. (doi:10.2527/jas.2012-5629)

Liu Q, Yan H, Dawes NJ, Mottino GA, Frank JS \& Zhu H 1996 Insulin-like growth factor II induces DNA synthesis in fetal ventricular myocytes in vitro. Circulation Research 79 716-726. (doi:10.1161/01.RES.79.4.716)

Long NM, Ford SP \& Nathanielsz PW 2011 Maternal obesity eliminates the neonatal lamb plasma leptin peak. Journal of Physiology 589 1455-1462. (doi:10.1113/jphysiol.2010.201681)

Louey S, Cock ML, Stevenson KM \& Harding R 2000 Placental insufficiency and fetal growth restriction lead to postnatal hypotension and altered postnatal growth in sheep. Pediatric Research 48 808-814. (doi:10.1203/ 00006450-200012000-00018)

Louey S, Jonker SS, Giraud GD \& Thornburg KL 2007 Placental insufficiency decreases cell cycle activity and terminal maturation in fetal sheep cardiomyocytes. Journal of Physiology $\mathbf{5 8 0}$ 639-648. (doi:10.1113/ jphysiol.2006.122200)

Lumbers ER, Boyce AC, Joulianos G, Kumarasamy V, Barner E, Segar JL \& Burrell JH 2005 Effects of cortisol on cardiac myocytes and on expression of cardiac genes in fetal sheep. American Journal of Physiology. Regulatory, Integrative and Comparative Physiology 288 R567-R574. (doi:10.1152/ajpregu.00556.2004)

Lumbers ER, Kim MY, Burrell JH, Kumarasamy V, Boyce AC, Gibson KJ, Gatford KL \& Owens JA 2009 Effects of intrafetal IGF-I on growth of cardiac myocytes in late-gestation fetal sheep. American Journal of Physiology. Endocrinology and Metabolism 296 E513-E519. (doi:10.1152/ ajpendo.90497.2008)

Magyar DM, Fridshal D, Elsner CW, Glatz T, Eliot J, Klein AH, Lowe KC, Buster JE \& Nathanielsz PW 1980 Time-trend analysis of plasma cortisol concentrations in the fetal sheep in relation to parturition. Endocrinology 107 155-159. (doi:10.1210/endo-107-1-155)

Mai W, Janier MF, Allioli N, Quignodon L, Chuzel T, Flamant F \& Samarut J 2004 Thyroid hormone receptor $\alpha$ is a molecular switch of cardiac function between fetal and postnatal life. PNAS 101 10332-10337. (doi:10.1073/pnas.0401843101)

Marijianowski MM, van der Loos CM, Mohrschladt MF \& Becker AE 1994 The neonatal heart has a relatively high content of total collagen and type I collagen, a condition that may explain the less compliant state. Journal of the American College of Cardiology 23 1204-1208. (doi:10.1016/ 0735-1097(94)90612-2)

Martin C, Yu AY, Jiang BH, Davis L, Kimberly D, Hohimer AR \& Semenza GL 1998 Cardiac hypertrophy in chronically anemic fetal sheep: Increased vascularization is associated with increased myocardial expression of vascular endothelial growth factor and hypoxia-inducible factor 1. American Journal of Obstetrics and Gynecology 178 527-534. (doi:10.1016/S0002-9378(98)70433-8)

Mathur H, Brown BL, Krane EJ, Thomas AL \& Nathanielsz PW 1980 Thyroid hormone relationships in the fetal and newborn lamb. Biology of the Neonate 37 138-141. (doi:10.1159/000241265)

Maylie JG 1982 Excitation-contraction coupling in neonatal and adult myocardium of cat. American Journal of Physiology 242 H834-H843.

Menche J, Sharma A, Kitsak M, Ghiassian SD, Vidal M, Loscalzo J \& Barabasi AL 2015 Disease networks. Uncovering disease-disease relationships through the incomplete interactome. Science $\mathbf{3 4 7}$ 1257601. (doi:10.1126/science.1257601)

Mihailidou AS, Loan Le TY, Mardini M \& Funder JW 2009 Glucocorticoids activate cardiac mineralocorticoid receptors during experimental myocardial infarction. Hypertension 54 1306-1312. (doi:10.1161/ HYPERTENSIONAHA.109.136242) 
Milani-Nejad N \& Janssen PM 2014 Small and large animal models in cardiac contraction research: advantages and disadvantages. Pharmacology and Therapeutics 141 235-249. (doi:10.1016/j.pharmthera.2013. 10.007)

Mollova M, Bersell K, Walsh S, Savla J, Das LT, Park SY, Silberstein LE, Dos Remedios CG, Graham D, Colan S et al. 2013 Cardiomyocyte proliferation contributes to heart growth in young humans. PNAS 110 1446-1451. (doi:10.1073/pnas.1214608110)

Morin FC III \& Egan EA 1992 Pulmonary hemodynamics in fetal lambs during development at normal and increased oxygen tension. Journal of Applied Physiology 73 213-218.

Morrison JL, Botting KJ, Dyer JL, Williams SJ, Thornburg KL \& McMillen IC 2007 Restriction of placental function alters heart development in the sheep fetus. American Journal of Physiology. Regulatory, Integrative and Comparative Physiology 293 R306-R313. (doi:10.1152/ajpregu.00798. 2006)

Murotsuki J, Gagnon R, Matthews SG \& Challis JR 1996 Effects of long-term hypoxemia on pituitary-adrenal function in fetal sheep. American Journal of Physiology 271 E678-E685.

Murotsuki J, Challis JR, Han VK, Fraher LJ \& Gagnon R 1997 Chronic fetal placental embolization and hypoxemia cause hypertension and myocardial hypertrophy in fetal sheep. American Journal of Physiology 272 R201-R207.

Norris AW, Bahr TM, Scholz TD, Peterson ES, Volk KA \& Segar JL 2014 Angiotensin II-induced cardiovascular load regulates cardiac remodeling and related gene expression in late-gestation fetal sheep. Pediatric Research 75 689-696. (doi:10.1038/pr.2014.37)

Olivetti G, Melissari M, Capasso JM \& Anversa P 1991 Cardiomyopathy of the aging human heart. Myocyte loss and reactive cellular hypertrophy. Circulation Research 68 1560-1568. (doi:10.1161/01.RES.68.6.1560)

Olson AK, Protheroe KN, Segar JL \& Scholz TD 2006 Mitogen-activated protein kinase activation and regulation in the pressure-loaded fetal ovine heart. American Journal of Physiology. Heart and Circulatory Physiology 290 H1587-H1595. (doi:10.1152/ajpheart.00984.2005)

O'Tierney PF, Chattergoon NN, Louey S, Giraud GD \& Thornburg KL 2010a Atrial natriuretic peptide inhibits angiotensin II-stimulated proliferation in fetal cardiomyocytes. Journal of Physiology $\mathbf{5 8 8}$ 2879-2889. (doi:10.1113/jphysiol.2010.191098)

O'Tierney PF, Anderson DF, Faber JJ, Louey S, Thornburg KL \& Giraud GD $2010 b$ Reduced systolic pressure load decreases cell-cycle activity in the fetal sheep heart. American Journal of Physiology. Regulatory, Integrative and Comparative Physiology 299 R573-R578. (doi:10.1152/ajpregu. 00754.2009)

Owens JA, Kind KL, Carbone F, Robinson JS \& Owens PC 1994 Circulating insulin-like growth factors-I and -II and substrates in fetal sheep following restriction of placental growth. Journal of Endocrinology 140 5-13. (doi:10.1677/joe.0.1400005)

Oyama K, El-Nachef D, Zhang Y, Sdek P \& MacLellan WR 2014 Epigenetic regulation of cardiac myocyte differentiation. Frontiers in Genetics 5375. (doi:10.3389/fgene.2014.00375)

Padbury JF, Klein AH, Polk DH, Lam RW, Hobel C \& Fisher DA 1986 Effect of thyroid status on lung and heart $\beta$-adrenergic receptors in fetal and newborn sheep. Developmental Pharmacology and Therapeutics 9 44-53.

Paradis AN, Gay MS \& Zhang L 2014 Binucleation of cardiomyocytes: the transition from a proliferative to a terminally differentiated state. Drug Discovery Today 19 602-609. (doi:10.1016/j.drudis.2013.10.019)

Perez-Castillo A, Bernal J, Ferreiro B \& Pans T 1985 The early ontogenesis of thyroid hormone receptor in the rat fetus. Endocrinology 117 2457-2461. (doi:10.1210/endo-117-6-2457)

Pessanha MG \& Mandarim-de-Lacerda CA 2000 Influence of the chronic nitric oxide synthesis inhibition on cardiomyocytes number. Virchows Archiv 437 667-674. (doi:10.1007/s004280000276)

Pijnappels DA, Gregoire S \& Wu SM 2010 The integrative aspects of cardiac physiology and their implications for cell-based therapy. Annals of the New York Academy of Sciences 1188 7-14. (doi:10.1111/j.1749-6632. 2009.05077.x)
Pinson CW, Morton MJ \& Thornburg KL 1987 An anatomic basis for fetal right ventricular dominance and arterial pressure sensitivity. Journal of Developmental Biology 9 253-269.

Polk DH 1995 Thyroid hormone metabolism during development. Reproduction, Fertility, and Development 7 469-477. (doi:10.1071/ RD9950469)

Polk DH, Callegari CC, Newnham J, Padbury JF, Reviczky A, Fisher DA \& Klein AH 1987 Effect of fetal thyroidectomy on newborn thermogenesis in lambs. Pediatric Research 21 453-457. (doi:10.1203/00006450198705000-00006)

Polk D, Cheromcha D, Reviczky A \& Fisher DA 1989 Nuclear thyroid hormone receptors: ontogeny and thyroid hormone effects in sheep. American Journal of Physiology 256 E543-E549.

Poolman RA, Li JM, Durand B \& Brooks G 1999 Altered expression of cell cycle proteins and prolonged duration of cardiac myocyte hyperplasia in p27KIP1 knockout mice. Circulation Research 85 117-127. (doi:10.1161/01.RES.85.2.117)

Qi Y, Xu Z, Zhu Q, Thomas C, Kumar R, Feng H, Dostal DE, White MF, Baker KM \& Guo S 2013 Myocardial loss of IRS1 and IRS2 causes heart failure and is controlled by p38 $\alpha$ MAPK during insulin resistance. Diabetes 62 3887-3900. (doi:10.2337/db13-0095)

Reini SA, Dutta G, Wood CE \& Keller-Wood M 2008 Cardiac corticosteroid receptors mediate the enlargement of the ovine fetal heart induced by chronic increases in maternal cortisol. Journal of Endocrinology 198 419-427. (doi:10.1677/JOE-08-0022)

Reini SA, Wood CE \& Keller-Wood M 2009 The ontogeny of genes related to ovine fetal cardiac growth. Gene Expression Patterns 9 122-128. (doi:10.1016/j.gep.2008.09.003)

Richards EM, Rabaglino MB, Antolic A, Wood CE \& Keller-Wood M 2015 Patterns of gene expression in the sheep heart during the perinatal period revealed by transcriptomic modeling. Physiological Genomics $\mathbf{4 7}$ 407-419. (doi:10.1152/physiolgenomics.00027.2015)

Rog-Zielinska EA, Thomson A, Kenyon CJ, Brownstein DG, Moran CM, Szumska D, Michailidou Z, Richardson J, Owen E, Watt A et al. 2013 Glucocorticoid receptor is required for foetal heart maturation. Human Molecular Genetics 22 3269-3282. (doi:10.1093/hmg/ddt182)

Rosenfeld CR, Samson WK, Roy TA, Faucher DJ \& Magness RR 1992 Vasoconstrictor-induced secretion of ANP in fetal sheep. American Journal of Physiology 263 E526-E533.

Rosenfeld CR, Gresores A, Roy TA \& Magness RR 1995 Comparison of ANG II in fetal and pregnant sheep: metabolic clearance and vascular sensitivity. American Journal of Physiology 268 E237-E247.

Rudolph AM 2009 Congenital Diseases of the Heart: Clinical-Physiological Considerations. Chichester, UK; Hoboken, NJ: Wiley-Blackwell.

Rumyantsev PP 1991 Growth and Hyperplasia of Cardiac Muscle Cells. New York, NY: Harwood Academic Publishers.

Samson F, Bonnet N, Heimburger M, Rucker-Martin C, Levitsky DO, Mazmanian GM, Mercadier JJ \& Serraf A 2000 Left ventricular alterations in a model of fetal left ventricular overload. Pediatric Research 48 43-49. (doi:10.1203/00006450-200007000-00010)

Sandgren J, Scholz TD \& Segar JL 2015 ANG II modulation of cardiac growth and remodeling in immature fetal sheep. American Journal of Physiology. Regulatory, Integrative and Comparative Physiology 308 R965-R972. (doi:10.1152/ajpregu.00034.2015)

Scroop GC, Stankewytsch-Janusch B \& Marker JD 1992 Renin-angiotensin and autonomic mechanisms in cardiovascular homeostasis during haemorrhage in fetal and neonatal sheep. Journal of Developmental Biology 18 25-33.

Segar JL, Scholz TD, Bedell KA, Smith OM, Huss DJ \& Guillery EN 1997 Angiotensin AT1 receptor blockade fails to attenuate pressure-overload cardiac hypertrophy in fetal sheep. American Journal of Physiology $\mathbf{2 7 3}$ R1501-R1508.

Segar JL, Dalshaug GB, Bedell KA, Smith OM \& Scholz TD 2001 Angiotensin II in cardiac pressure-overload hypertrophy in fetal sheep. American Journal of Physiology. Regulatory, Integrative and Comparative Physiology 281 R2037-R2047.

Published by Bioscientifica Ltd 
Segar JL, Volk KA, Lipman MH \& Scholz TD 2013 Thyroid hormone is required for growth adaptation to pressure load in the ovine fetal heart. Experimental Physiology 98 722-733. (doi:10.1113/expphysiol.2012. 069435)

Seki S, Nagashima M, Yamada Y, Tsutsuura M, Kobayashi T, Namiki A \& Tohse N 2003 Fetal and postnatal development of Ca2 + transients and $\mathrm{Ca} 2+$ sparks in rat cardiomyocytes. Cardiovascular Research $\mathbf{5 8}$ 535-548. (doi:10.1016/S0008-6363(03)00255-4)

Sensky PL, Roy CH, Barnes RJ \& Heath MF 1994 Changes in fetal thyroid hormone levels in adrenalectomized fetal sheep following continuous cortisol infusion $72 \mathrm{~h}$ before delivery. Journal of Endocrinology $\mathbf{1 4 0}$ 79-83. (doi:10.1677/joe.0.1400079)

Sheridan DJ, Cullen MJ \& Tynan MJ 1979 Qualitative and quantitative observations on ultrastructural changes during postnatal development in the cat myocardium. Journal of Molecular and Cellular Cardiology $\mathbf{1 1}$ 1173-1181. (doi:10.1016/S0022-2828(79)80004-8)

Siegel SR \& Fisher DA 1980 Ontogeny of the renin-angiotensin-aldosterone system in the fetal and newborn lamb. Pediatric Research 14 99-102. (doi:10.1203/00006450-198002000-00006)

Silberbach M, Woods LL, Hohimer AR, Shiota T, Matsuda Y \& Davis LE 1995 Role of endogenous atrial natriuretic peptide in chronic anemia in the ovine fetus: effects of a non-peptide antagonist for atrial natriuretic peptide receptor. Pediatric Research 38 722-728. (doi:10.1203/ 00006450-199511000-00015)

Smolich JJ, Walker AM, Campbell GR \& Adamson TM 1989 Left and right ventricular myocardial morphometry in fetal, neonatal, and adult sheep. American Journal of Physiology 257 H1-H9.

Soonpaa MH, Kim KK, Pajak L, Franklin M \& Field LJ 1996 Cardiomyocyte DNA synthesis and binucleation during murine development. American Journal of Physiology 271 H2183-H2189.

Stahlman M, Gray J, Young WC \& Shepard FM 1967 Cardiovascular response of the neonatal lamb to hypoxia and hypercapnia. American Journal of Physiology 213 899-904.

Strait KA, Schwartz HL, Perez-Castillo A \& Oppenheimer JH 1990 Relationship of c-erbA mRNA content to tissue triiodothyronine nuclear binding capacity and function in developing and adult rats. Journal of Biological Chemistry 265 10514-10521.

Sundgren NC, Giraud GD, Stork PJ, Maylie JG \& Thornburg KL 2003a Angiotensin II stimulates hyperplasia but not hypertrophy in immature ovine cardiomyocytes. Journal of Physiology 548 881-891. (doi:10.1113/ jphysiol.2003.038778)
Sundgren NC, Giraud GD, Schultz JM, Lasarev MR, Stork PJ \& Thornburg KL 2003b Extracellular signal-regulated kinase and phosphoinositol-3 kinase mediate IGF-1 induced proliferation of fetal sheep cardiomyocytes. American Journal of Physiology. Regulatory, Integrative and Comparative Physiology 285 R1481-R1489. (doi:10.1152/ ajpregu.00232.2003)

Sundgren NC, Giraud GD, Stork PJ, Maylie JG \& Thornburg KL 2003c Angiotensin II stimulates hyperplasia but not hypertrophy in immature ovine cardiomyocytes. Journal of Physiology 548 881-891. (doi:10.1113/ jphysiol.2003.038778)

Tangalakis K, Lumbers ER, Moritz KM, Towstoless MK \& Wintour EM 1992 Effect of cortisol on blood pressure and vascular reactivity in the ovine fetus. Experimental Physiology 77 709-717. (doi:10.1113/expphysiol. 1992.sp003637)

The NS, Adair LS \& Gordon-Larsen P 2010 A study of the birth weightobesity relation using a longitudinal cohort and sibling and twin pairs. American Journal of Epidemiology 172 549-557. (doi:10.1093/aje/ kwq169)

Thornburg K, Jonker S, O’Tierney P, Chattergoon N, Louey S, Faber J \& Giraud G 2011 Regulation of the cardiomyocyte population in the developing heart. Progress in Biophysics and Molecular Biology 106 289-299. (doi:10.1016/j.pbiomolbio.2010.11.010)

Uzun O, Wilson DG, Vujanic GM, Parsons JM \& De Giovanni JV 2007 Cardiac tumours in children. Orphanet Journal of Rare Diseases 211. (doi:10.1186/1750-1172-2-11)

Velaphi SC, Despain K, Roy T \& Rosenfeld CR 2007 The renin-angiotensin system in conscious newborn sheep: metabolic clearance rate and activity. Pediatric Research 61 681-686. (doi:10.1203/pdr. Ob013e3180534252)

Wang KC, Brooks DA, Botting KJ \& Morrison JL 2012 IGF-2R-mediated signaling results in hypertrophy of cultured cardiomyocytes from fetal sheep. Biology of Reproduction 86 183. (doi:10.1095/biolreprod.112. 100388)

Wearn JT 1941 Morphological and functional alterations of the coronary circulation: Harvey Lecture, April 18, 1940. Bulletin of the New York Academy of Medicine 17 754-777.

White FC, McKirnan MD, Breisch EA, Guth BD, Liu YM \& Bloor CM 1987 Adaptation of the left ventricle to exercise-induced hypertrophy. Journal of Applied Physiology 62 1097-1110. (doi:10.1063/1.339715)

Wood CE, Cheung CY \& Brace RA 1987 Fetal heart rate, arterial pressure, and blood volume responses to cortisol infusion. American Journal of Physiology 253 R904-R909.

Received in final form 20 August 2015

Accepted 1 October 2015

Accepted Preprint published online 2 October 2015
(C) 2016 Society for Endocrinology Printed in Great Britain 